Article

\title{
Water Quality Problems Analysis and Assessment of the Ecological Security Level of the Transboundary Ural-Caspian Basin of the Republic of Kazakhstan
}

\author{
Nariman Amirgalievich Amirgaliev ${ }^{1}$, Maulken Askarova ${ }^{2}$, Christian Opp ${ }^{3, *}$, Alikhan Medeu ${ }^{1}$, \\ Roza Kulbekova ${ }^{1, *}$ and Akhmetkal Rakhmetullayevich Medeu ${ }^{1}$
}

Citation: Amirgaliev, N.A.; Askarova, M.; Opp, C.; Medeu, A.; Kulbekova,

R.; Medeu, A.R. Water Quality

Problems Analysis and Assessment of the Ecological Security Level of the Transboundary Ural-Caspian Basin of the Republic of Kazakhstan. Appl. Sci. 2022, 12, 2059. https://doi.org/ 10.3390/app12042059

Academic Editors: António José Madeira Nogueira and Miren López de Alda Villaizán

Received: 3 May 2021

Accepted: 11 September 2021

Published: 16 February 2022

Publisher's Note: MDPI stays neutral with regard to jurisdictional claims in published maps and institutional affiliations.

Copyright: (C) 2022 by the authors. Licensee MDPI, Basel, Switzerland. This article is an open access article distributed under the terms and conditions of the Creative Commons Attribution (CC BY) license (https:// creativecommons.org/licenses/by/ $4.0 /)$.
1 Institute of Geography and Water Security, Ministry of Education \& Science, Almaty 050010, Kazakhstan; namirgaliev.n.a@ingeo.kz (N.A.A.); medeu.a.a@ingeo.kz (A.M.); medeu.ar@ingeo.kz (A.R.M.)

2 Department of Geography, Land Management and Cadastre, Al-Farabi Kazakh National University, Almaty 050038, Kazakhstan; askarova.maulken@kaznu.kz

3 Faculty of Geography, Philipps-Universität Marburg, D-35032 Marburg, Germany

* Correspondence: opp@geo.uni-marburg.de (C.O.); kulbekova@ingeo.kz (R.K.)

\begin{abstract}
Both the insufficiency of water resources and the contamination of even transboundary water bodies are serious problems. Water quality analyses of the transboundary (between Russia and Kazakhstan) Ural River and the Kazakh sector of the Caspian Sea, and their assessment are the main research questions of this study. It is shown that the Ural River is heavily contaminated by polychlorinated biphenyls, heavy metals, oil contaminants, and pesticides, arising from industrial enterprises and agricultural objects. The results show that these toxicants are not only present in water, but they are also accumulated in the muscular tissues of all fish (Abramis brama, Sander lucioperca, Aspius aspius). The Caspian Sea is heavily contaminated by petroleum hydrocarbons due to off shore oil production. A sufficiently high level of accumulation of petroleum hydrocarbons, organochlorine pesticides and heavy metals was determined in the muscles of Caspian fish. All these contaminations lead to the loss of biodiversity and bio-productivity of the Caspian Sea. The authors propose a methodology for a quantitative assessment of the environmental safety level in relation to the Kazakh part of the Caspian Sea, based on bioindication methods. Recommendations, aimed for maintaining acceptable values of water resources quality, are suggested.
\end{abstract}

Keywords: transboundary water courses; Ural River; contaminants; Caspian Sea; fish; ecological safety; bioindication

\section{Introduction}

Water is the main essential resource of humanity, which is necessary for its survival. Today the relevance of problems related to water resources has been recognized throughout the world and is intensively studied [1-3]. Water resources problems are highly interconnected with global climate change, as its influence on the distribution and circulation of water in the environment is observed [4-6].

The Republic of Kazakhstan is located in the center of the Eurasian continent. Kazakhstan has own specific climatic and geographical conditions (Figure 1). The most characteristic feature of Kazakhstan is its inland position. Therefore, the majority of the Kazakh territory is without river runoff. Kazakhstan is characterized by a sharply continental climate, the predominance of arid zones, scarcity, and diverse distribution of water resources. In this regard, water resources problems are the dominant factor in environmental destabilization at present time and in the future. The Republic of Kazakhstan ranks last among the countries of the Commonwealth of Independent States (CIS) in terms of water availability [7]. Today, more than a third of the Kazakh population does not have permanent access to quality potable water, and by 2050 it may be impossible to meet the demand for 
water [7-9]. That is why, there is a risk of severe water scarcity, what means that Kazakhstan could be on the list of States of disastrous water stress.

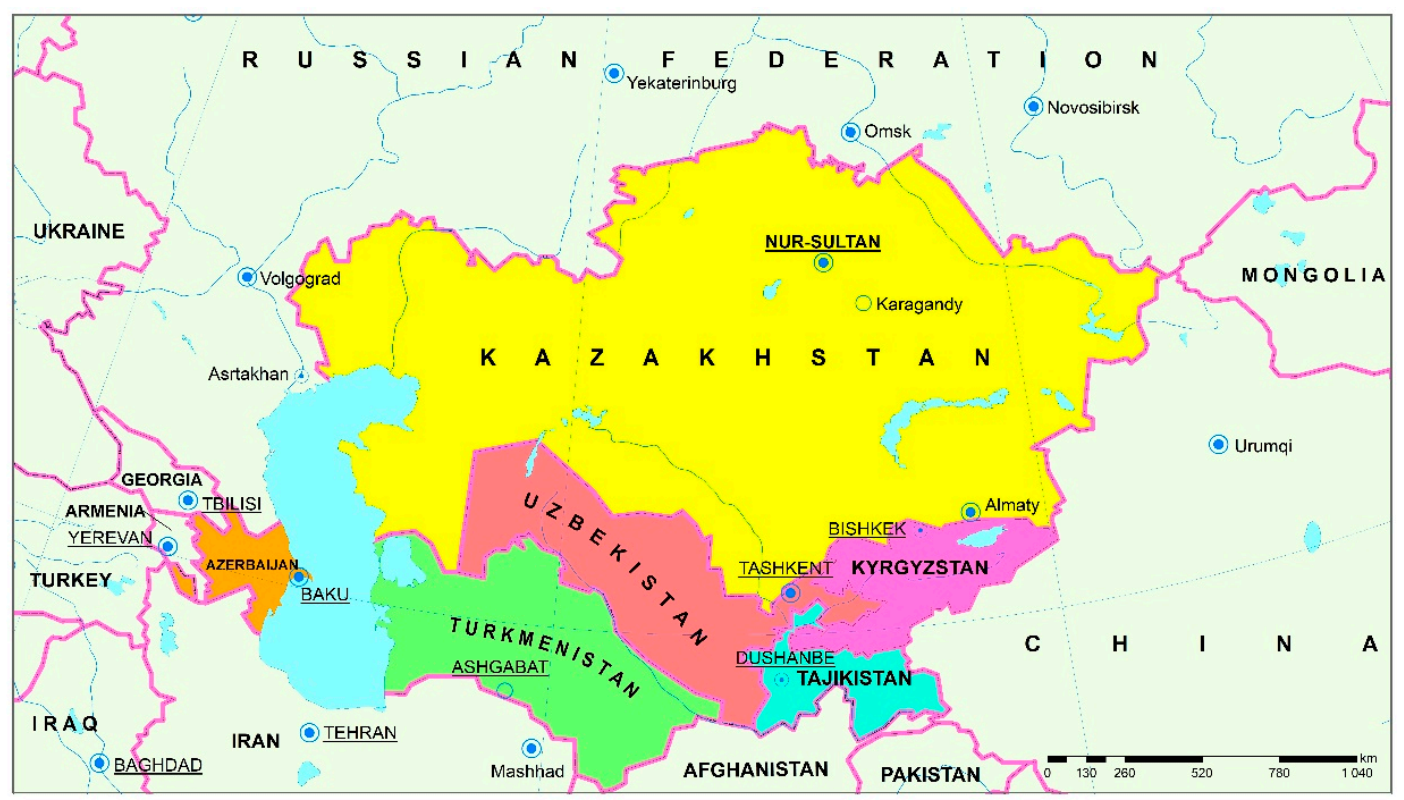

Figure 1. Location of the Republic of Kazakhstan (source: Institute of Geography and Water Security, Almaty, Kazakhstan).

According to A.R. Medeu et al. [8] and L.S. Toleubayeva [9] the total water flow in Kazakhstan in the early 1960s was $126.0 \mathrm{~km}^{3}$ /year. In the $1970 \mathrm{~s}$, it has decreased to $115.0 \mathrm{~km}^{3}$ /year, and in the $1990 \mathrm{~s}$ it fell to $100.5 \mathrm{~km}^{3}$ /year. After analyzing the long-term flow changes, it can be concluded that now the annual flow is only $91.3 \mathrm{~km}^{3} /$ year, of which $47.0 \mathrm{~km}^{3}$ /year is formed within the territory of Kazakhstan. The rest of the water is transboundary water, coming from neighboring countries.

According to experts' estimation, by 2020 , the runoff will be $81.6 \mathrm{~km}^{3} /$ year, and by $2030-72.4 \mathrm{~km}^{3} /$ year, with a government-wide consumption rate of $88-90 \mathrm{~km}^{3} /$ year (Figure 2). As shown, the total reduction of surface runoff is mainly due to the reduction of transboundary runoff [9].

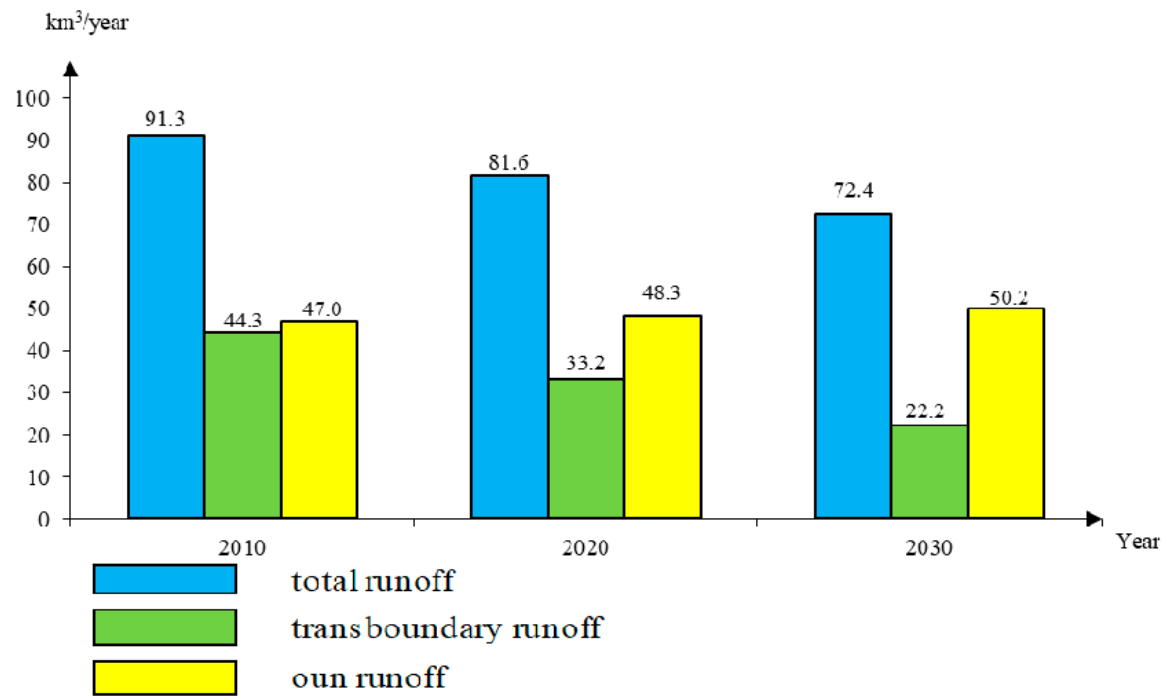

Figure 2. Surface runoff of the Republic of Kazakhstan [8]. 
The main purpose of the UN Convention Economic Commission for Europe (UNECE) 2013 on transboundary waters is to strengthen measures at local, national and transboundary levels to protect and ensure the quality, quantity and sustainable use of transboundary water resources. As a full member of the UN, Kazakhstan, based on a global partnership, should use international cooperation for the effective implementation of state environmental policy, including the use of water and biological resources of transboundary water courses and reservoirs.

In general, there are 8 water management basins in the Republic of Kazakhstan (Figure 3), 7 of which are transboundary, such as Irtysh (Yertis), Ili (Ile), Syr Darya, Ural (Zhaiyk).

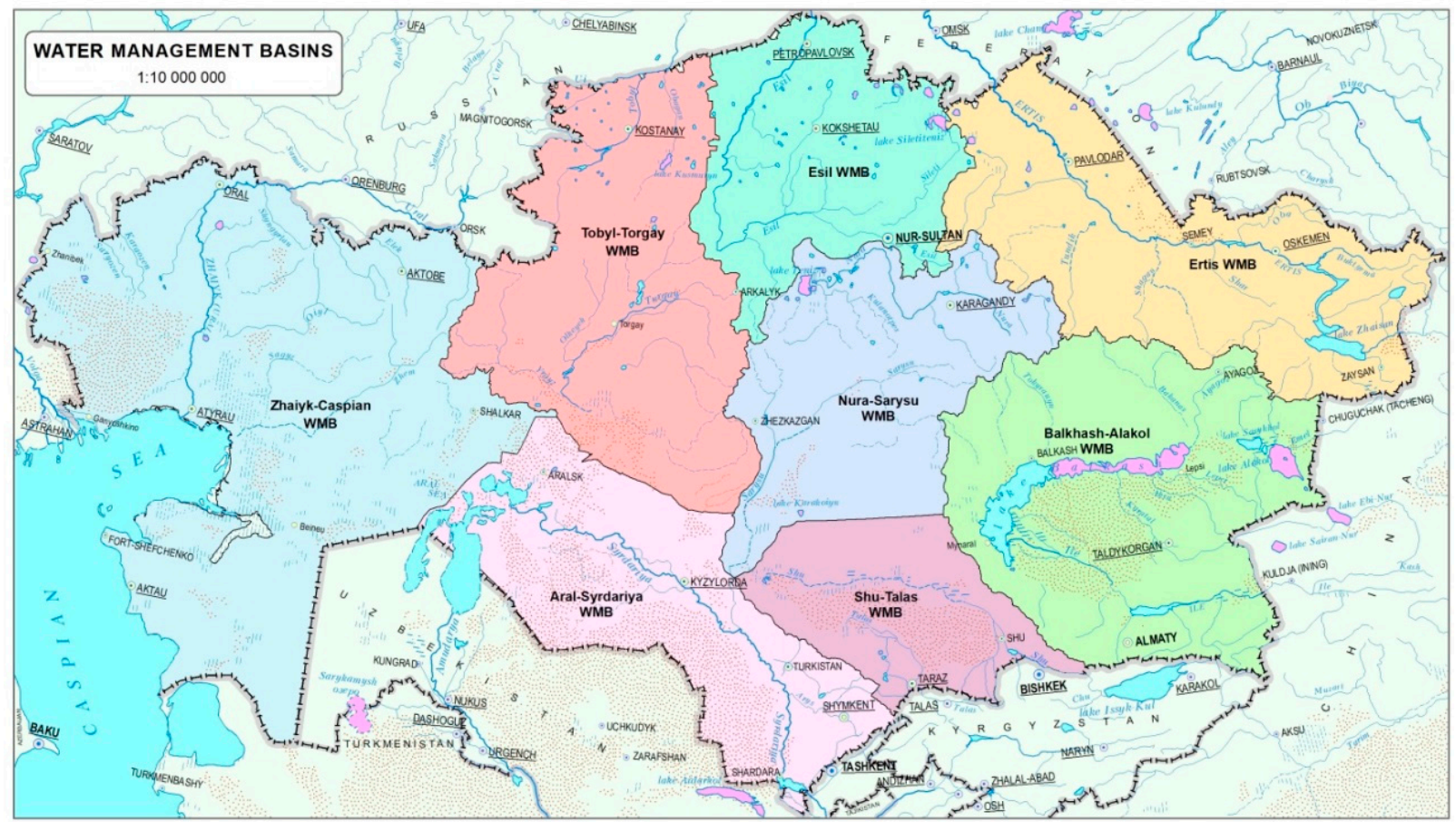

Figure 3. Water management basins of Kazakhstan (source: Institute of Geography and Water Security, Almaty, Kazakhstan) [8].

An important problem is not only to maintain the optimal volume of river water inflow into the water basins, but also to ensure the quality conditions, since in most cases transboundary water courses contain toxic compounds brought from the territory of countries located upstream.

Among potential pollutants inorganic heavy metals, such as cadmium $(\mathrm{Cd})$, manganese $(\mathrm{Mn})$, nickel $(\mathrm{Ni})$, cobalt $(\mathrm{Co})$, zinc $(\mathrm{Zn})$, copper $(\mathrm{Cu})$, chrome $(\mathrm{Cr})$, lead $(\mathrm{Pb})$, mercury (Hg), iron (Fe) (c.f. [10-14]) and organic compounds, such as polycyclic aromatic hydrocarbons (PAHs), volatile chlorinated hydrocarbons (VOCs) (c.f. [11,15]), heterocyclic aromatic hydrocarbons (HAHs), aromatic amines, dioxins and furans [11], and different petro-chemical products [16] plastics and microplastics [17] with their different sorption and desorption capacities are wide spread both in industrial and mining areas [12] and in and around large urban concentrations. Concentrations, spatial distributions along and across the rivers, migration behavior of these pollutants during flood and within floodplain soil profiles were analyzed and assessed by these and many other authors. Due to the fact that most of the big rivers cross state borders, transporting their pollutant load from the upper section of the catchment to the lower section or to the sea, systemic studies of the transboundary rivers water resources, their suspended matter and their fluvial sediments is an extremely important task, also for Kazakhstan [18]. 
One of the largest and most important water basins of Kazakhstan, especially for Northwest Kazakhstan, is the Ural-Caspian basin, where not only the Ural River is a transboundary water body, but also the Caspian Sea is shared by five Caspian states.

The Ural River (Zhaiyk) is the third longest river in Europe after Volga and Danube (total length $-2428 \mathrm{~km}$, including $1084 \mathrm{~km}$ on the territory of the Republic of Kazakhstan) with a basin area of $\sim 380$ thousand $\mathrm{km}^{2}$.

The upper basin is located on the territory of the Russian Federation (RF), and the lower part is in Aktobe, West Kazakhstan and Atyrau regions of Kazakhstan (Figure 4) [19]. The river marks the border between Europe and Asia. Another feature is that the main spawning of sturgeon roe, which are endemic species, can be found in the middle part of the Ural River.

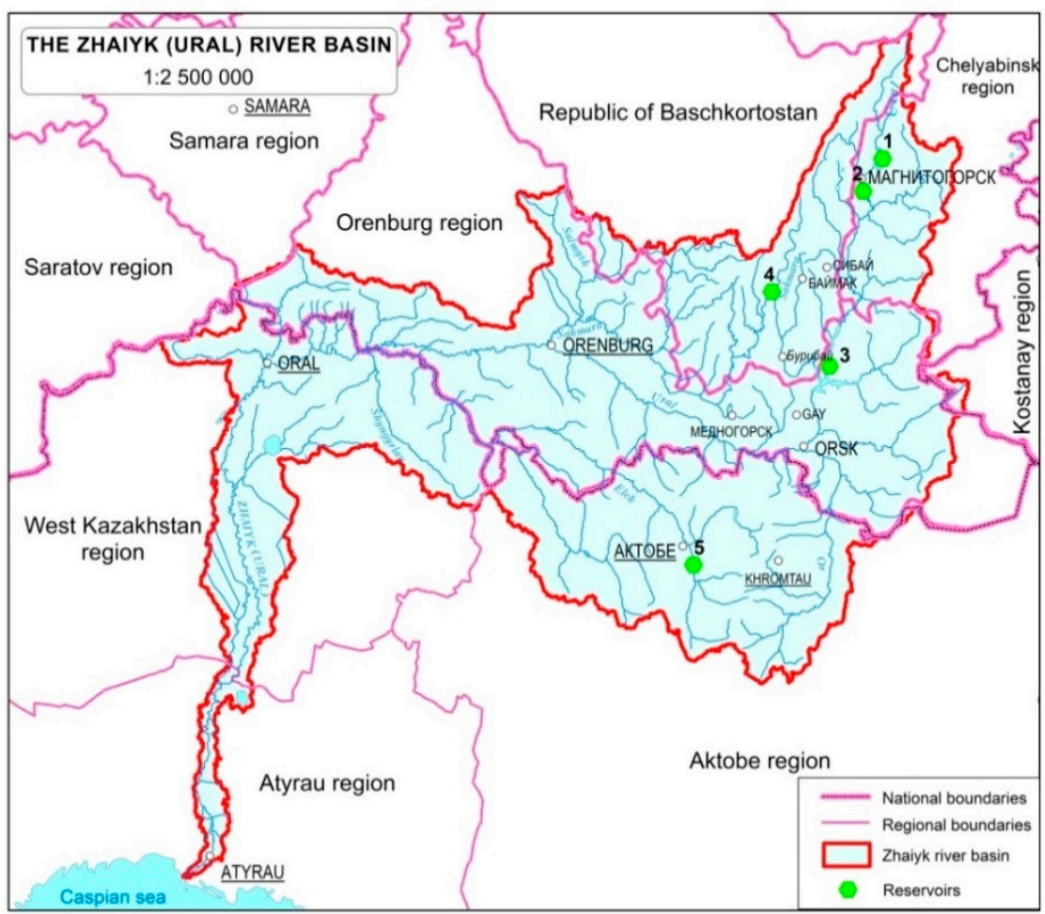

Figure 4. Transboundary basin of the Ural River. Reservoirs: 1-Verkhneuralskoye; 2-Magnitogorsk; 3-Iriklinskoye; 4-Sakmarskoye; 5-Aktobe [19].

Within international cooperation on shared water courses, a basin approach of integrated watercourse management recognized as a key solution to many problems, which allows taking into account the ecological state of the natural ecosystem, its stability and self-cleaning ability.

The problem of fair and equitable use of shared water courses with Russia is one of the important issues for the Republic of Kazakhstan. The Ural-Caspian water management basin includes the Ural River basin, the Kamysh-Samara lakes basin (the Karaozen and Saryozen rivers), and the Volga basin (the Kigash and Shora rivers).

In recent decades substantial changes in water resources, mainly water level drop down due to anthropogenic flow reductions, have been observed, which poses a serious threat to the sustainable development of the natural and economic system of Western Kazakhstan.

According to long-term data, since 1971, there has been a systematic and phased reduction of the average annual flow of the Ural River with a slight increase in 1990-1994. The value of the annual flow of the river compared to the long-term average [20], equal to $12.0 \mathrm{~km}^{3}$, decreased: by 1995 - to an average of $10.0 \mathrm{~km}^{3}$, or $16.7 \%$, and by 2016 - to an average of $7.47 \mathrm{~km}^{3}$, or $37.8 \%$ [21] (Figure 5). 


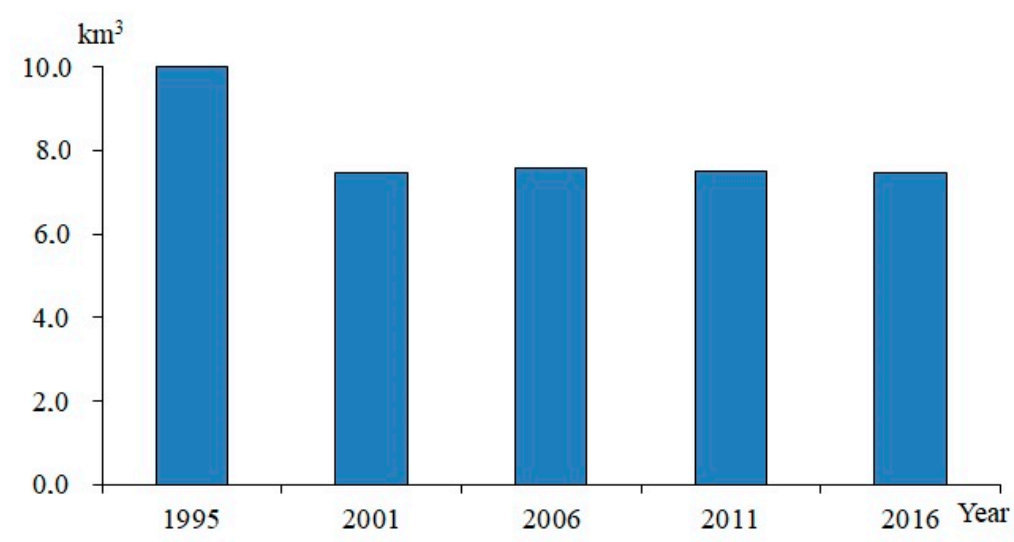

Figure 5. Long-term dynamic of the average annual runoff of the Ural River (Source: [21]).

In a study by Zh.T. Sivokhip et al. [19], there are currently 18 large and medium-sized reservoirs with a total volume of more than 5.5 million $\mathrm{m}^{3}$ in the Ural River basin on the territory of the Russian Federation. The largest among them (c.f. Figure 4) are the upper Ural $\left(600\right.$ million $\left.\mathrm{m}^{3}\right)$, Magnitogorsk $\left(190\right.$ million $\left.\mathrm{m}^{3}\right)$ and Iriklinsk $\left(3260\right.$ million $\left.\mathrm{m}^{3}\right)$ reservoirs. These reservoirs store the runoff of the upper and middle sections of the Ural River, which provide the needs of the population and all economy sectors.

Besides the reduction of the transboundary inflow, one of the threats to hydroecological security remains the anthropogenic impact on water resources of the Ural River. The technogenic contamination of the surface water of the Ural River basin carries on, resulting in a deep violation of the ecological balance of the river's ecosystems. The river receives a large amount of dredge, biogenic elements, heavy metals, and contaminated material of anthropogenic origin. According to long-term observations stable contaminations of water courses have been mentioned. Many of the parameters exceed the maximum permissible concentration (MPC) values for surface water [19,22-25].

The purpose of our research is to show the importance of not only regulating the amount of water flow in transboundary basins, but also the quality of water resources; to identify the main problems that have arisen in the field of water quality in the Ural-Caspian basin, and to develop recommendations for assessing the level of environmental safety and reducing anthropogenic pressure in the basin.

To achieve the goals, the following tasks were completed:

- demonstrate that the climatic and geographical conditions of Kazakhstan determine the predominance of arid zones, scarcity of water resources and the transboundary nature of the country's main river basins, including Ural-Caspian basin;

- study the ecological conditions of the transboundary Ural River and its pollution level by different toxic compounds estimating the ecological condition of the Kazakh part of the Caspian Sea and the level, dynamics, and distribution of pollutants (petroleum hydrocarbons, heavy metals and pesticides) in its water area and their influence on biological resources

- proposing a methodology for a quantitative assessment of the ecological safety level of the Kazakh part of the Caspian Sea;

- offer recommendations for maintaining the standard quality of water resources in the Ural-Caspian basin, and improve the ecological conditions and habitats of the aquatic fauna.

\section{Materials and Methods}

The determination of Polychlorinated Biphenyls (PCBs) in water was carried out according to MU 1792-77 (Guidelines for the determination of organochlorine pesticides and polychlorinated biphenyls in their combined presence in environmental objects and biomaterial) using gas chromatograph «Chromos GH-1000»; electron capture detector (ECD) and capillary column $220 \mathrm{C}$, evaporator temperature $240{ }^{\circ} \mathrm{C}$, detector temperature 
$300^{\circ} \mathrm{C}$, gas consumption carrier (nitrogen «ultrapure») $-38 \mathrm{~mL} / \mathrm{min}$. As a standard, we used the GSO of the composition of a Sovol solution in hexane, which is a mixture of PCB-52, PCB-101, PCB-138, PCB-153 and the sum of tetra-, penta, and hexachlorobiphenyls.

The content of petroleum products both in water and fish was determined in the «Scientific and Analytical Center «Biomedpreparat» (company "Laborfarma", Almaty, Kazakhstan) by the GLC method on a gas chromatograph Hewlett Packard 6890 (USA) with a flame ionization detector (FID). The separation of hydrocarbons was performed on a capillary column DB-608, $30 \mathrm{~m} \times 0.53 \mathrm{~mm}$ with a film thickness of $0.83 \mu \mathrm{m}$. The quantitative determination of the total content of petroleum hydrocarbons in water samples was performed using FID calibration with a solution of a standard oil sample in the concentration range from 1 to $10 \mathrm{mg} / \mathrm{mL}$ [26], in fish samples a solution of a standard sample $\mathrm{C}_{10}-\mathrm{C}_{40}$ from the company FlukaLot 0001452805, Almaty, Kazakhstan was used.

Heavy metals were determined by the method of atomic absorption with atomization in a flame using the mercury-hydride prefix TIAS 100 on the atomic absorption spectrometer analyst 300 from the Perkin Elmer.

The determination of organochlorine pesticides (Dichlordiphenyltrichlorethan or DDT and Hexachlorocyclohexane or $\mathrm{HCH}$ ) both in water and in fish muscles was performed on a gas chromatograph using the same method used to determine PCBs, as indicated above, taking into account different chromatography conditions for PCBs and organochlorine pesticides.

To assess the contaminants level in water, the MPC for fisheries management reservoirs was used [27-30]. Other existing MPCs used are [31] presented in Table 1.

Table 1. Maximum permissible concentrations (MPC) of heavy metals and organic pollutants in water bodies, in $\mathrm{mg} / \mathrm{L}$.

\begin{tabular}{|c|c|c|c|c|c|c|c|}
\hline \multirow{3}{*}{ Element } & \multirow{3}{*}{ Unit } & \multicolumn{3}{|c|}{ MPC } & \multirow{3}{*}{ WHO } & \multirow{3}{*}{$\begin{array}{l}\text { USEPA } \\
\text { (USA) }\end{array}$} & \multirow{3}{*}{$\begin{array}{c}\text { EU } \\
\text { Directive }\end{array}$} \\
\hline & & \multirow{2}{*}{$\begin{array}{l}\text { for Domestic Drinking and } \\
\text { Cultural Water Supply }\end{array}$} & \multicolumn{2}{|c|}{ for Surface Water } & & & \\
\hline & & & $\begin{array}{c}\text { for Fishery } \\
\text { Water Bodies }\end{array}$ & $\begin{array}{l}\text { for Sea } \\
\text { Water* }\end{array}$ & & & \\
\hline Cadmium & $\mathrm{mg} / \mathrm{L}$ & 0.001 & 0.005 & 0.01 & 0.003 & 0.005 & 0.005 \\
\hline Cobalt & $\mathrm{mg} / \mathrm{L}$ & 0.1 & 0.01 & 0.005 & - & - & - \\
\hline Manganese & $\mathrm{mg} / \mathrm{L}$ & 0.1 & 0.01 & 0.05 & $0.5(0.1)$ & 0.05 & 0.05 \\
\hline Copper $(\mathrm{Cu})$ & $\mathrm{mg} / \mathrm{L}$ & 1 & 0.001 & 0.005 & $2(1.0)$ & $1.0-1.3$ & 2.0 \\
\hline Nickel & $\mathrm{mg} / \mathrm{L}$ & 0.1 & 0.01 & 0.01 & - & - & - \\
\hline Lead $(\mathrm{Pb})$ & $\mathrm{mg} / \mathrm{L}$ & 0.03 & 0.01 & 0.01 & 0.01 & 0.015 & 0.01 \\
\hline Zinc & $\mathrm{mg} / \mathrm{L}$ & 1 & 0.01 & 0.05 & 3.0 & 5.0 & 5.0 \\
\hline Chrome (VI) & $\mathrm{mg} / \mathrm{L}$ & 0.05 & 0.020 & - & 0.05 & 0.1 & 0.05 \\
\hline Chrome (III) & $\mathrm{mg} / \mathrm{L}$ & 0.5 & 0.005 & - & - & 0.1 & - \\
\hline $\begin{array}{c}\text { Petroleum } \\
\text { hydrocarbons }\end{array}$ & $\mathrm{mg} / \mathrm{L}$ & - & 0.05 & 0.05 & - & - & - \\
\hline $\begin{array}{l}\text { Polychlorinated } \\
\text { biphenyls (PCBs) }\end{array}$ & $\mu \mathrm{g} / \mathrm{L}$ & 1 & - & - & - & - & - \\
\hline
\end{tabular}

${ }^{*}$ Due to the fact, that there are no standards, especially for fish species in the Caspian Sea, seawater respectively marine water standards were used [27-31].

Comparing the MPC standards in force in different countries and according to the recommendation of the WHO, it is possible to conclude the following. The WHO, USEPA (USA) and EU standards are designed to assess the quality of potable water and their values are quite close to each other in a number of elements. Comparing them with the standards for potable water in the CIS, the latter are more stringent for metals such as cadmium, copper and zinc for manganese and lead, on the contrary, and for chromium (VI)-almost equivalent. 


\section{Results and Discussion}

\subsection{Heavy Metal Contamination in River Water and Sediments}

One of the priority contaminants of the Ural River are heavy metals. According to registered data [22,23], the river water within the territory of Kazakhstan contains on average: copper-up to $18 \mu \mathrm{g} / \mathrm{L}(18 \mathrm{MPC})$, zinc $-35 \mu \mathrm{g} / \mathrm{L}$ (3.5 MPC), lead and cobalt-40 $\mu \mathrm{g} / \mathrm{L}$ (4 MPC), nickel-80 $\mu \mathrm{g} / \mathrm{L}$ (8 MPC) and chromium $-60 \mu \mathrm{g} / \mathrm{L}$ (3 MPC) in comparison with the standards for fishery reservoirs [c.f. Table 1].

Numerous objects of mining and metallurgical industry are the determining factors of the technogenic transformation of the chemical composition of river water in the upper reaches of the Ural River within the territory of the Russian Federation for 50-60 years or more $[19,24]$. Long-term industrial development, emissions and accordingly mineral deposits in the Southern Trans-Ural are reasons for the formation of an increased background content of heavy metal ions and many other contaminants. All this, according to authors opinions, led to a significant weakening of such stability parameters (surge capacity) of river systems like deterioration of the drinking water quality, of the biodiversity conditions and of the sturgeon fish species reproduction.

The largest contamination is caused by the Magnitogorsk Metallurgical Plant, Buribaevsk, Gaisk, Uchalinsk Mining-and-Processing Integrated Works, Sibaysk and Bashkirsk copper and sulfur plants, Orsk oil refinery, South Ural nickel plant, Orsk-Khalilovsk metallurgical plant, Orenburg oil refinery, etc. [19,24]. From Magnitogorsk to Orsk, the authors determined the presence of 20 major contamination sources of surface waters. These sources are responsible for the high contamination level of the Ural River and its tributaries. Among them heavy metals, especially very high iron, zinc and copper concentrations are wide spread, and constantly exceed the level of fisheries MPC. Also the waters of some Ural River tributaries can be characterized by high and extremely high levels of these metals.

Studies [25] have shown that the level of heavy metal accumulation in the bottom sediments of the Ural River is characterized by the following data: the concentration of gross forms of iron exceeds the MPC $(25000 \mathrm{mg} / \mathrm{kg})$ at all sampling points by 1.6 to 2.4 times, the content of manganese showed an excess of the MPC $(1500 \mathrm{mg} / \mathrm{kg})$ in the Spasskiy village to $1.4 \mathrm{MPC}$, in the village Primorskiy and in the Magnitogorsk water reservoir-1.2 MPC.

The cadmium concentration of in the river sediments varied from 0.7 to $1.75 \mathrm{mg} / \mathrm{kg}$, which is 1.2 times higher than the permissible norms $(1.5 \mathrm{mg} / \mathrm{kg})$. The level of lead varied from 8.8 to $152.5 \mathrm{mg} / \mathrm{kg}$, i.e., the maximum permissible concentration $(32 \mathrm{mg} / \mathrm{kg})$ was 4.8 times higher.

Consequently, bottom sediments are powerful sources of secondary contamination of river water with these toxic compounds. It was found [32] that as a result of sewage emissions from the Orsk oil refinery almost all benthic groups and macrophytes sensitive to environmental conditions were killed in the Ural River at a site $15 \mathrm{~km}$ below the sewage discharge. The concentration of petroleum products in the floodplain soils reached $21.3 \mathrm{mg} / \mathrm{kg}$, in some places- $152 \mathrm{mg} / \mathrm{kg}$.

\subsection{Contamination by Polychlorinated Biphenyls (PCBs) in River Water}

The Ural River is also contaminated by persistent organic pollutants (POPs), namely polychlorinated biphenyls (PCBs). In accordance with the requirements of the Global Stockholm Convention on POPs, these substances are highly toxic for people and nature, and compounds needs to be studied in the natural environment, their use gradually reduced, and by 2028 they should be completely destroyed on Earth [33].

PCB concentrations between 0.93 and $1.29 \mu \mathrm{g} / \mathrm{L}$ were mentioned in the water of the lower course of the Ural River in 2012, according to analyses done by the Institute of Geography in Almaty. Still in 2005 the corresponding PCP level of the water of this section of the river was much lower. As can be seen from Figure 6, above Atyrau (Bugorki village), the PCB concentrations in water was $0.93 \mu \mathrm{g} / \mathrm{L}$. And at the beginning of the Ural-Caspian Canal, i.e., at the main-stream station along the main riverbed, it increased to $1.29 \mu \mathrm{g} / \mathrm{L}$. 
A similar pattern in the distribution of PCBs along the river was registered in 2005. This increase in the amount of toxicants downstream is obviously due to the influence of waste in the form of sewage and atmospheric emissions from numerous industrial enterprises located in Atyrau and a number of large settlements along the river banks towards the Caspian Sea. Relatively less contaminated water was founded in the less populated Right Yaitskiy Delta arm, which passes through a small part of the river. Removal of PCBs by river runoff led to their accumulation in the water of the pre-estuary Caspian Sea area up to $1.0 \mu \mathrm{g} / \mathrm{L}[34,35]$.

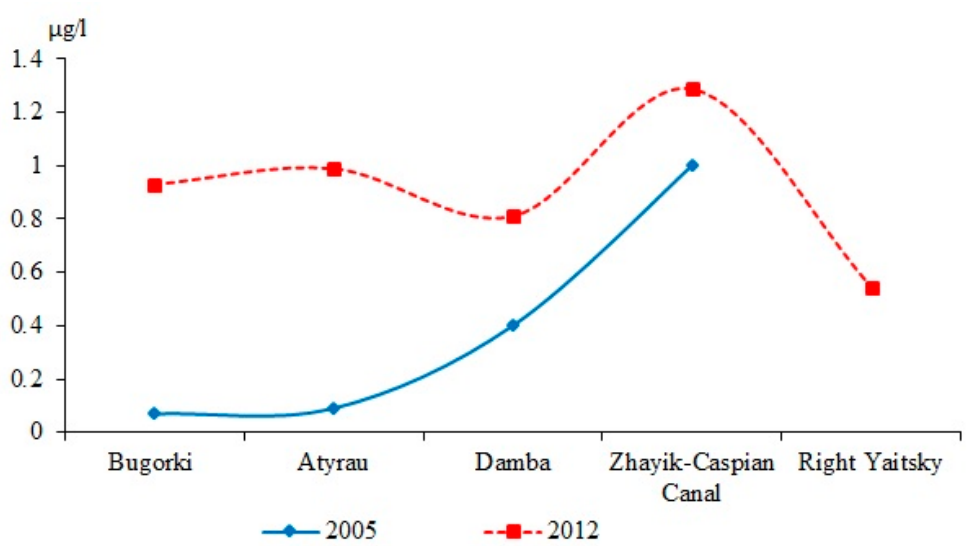

Figure 6. Change in PCB concentrations along the Ural River.

According to data [36,37], the standard of PCBs for potable water is $1.0 \mu \mathrm{g} / \mathrm{L}$. The same level of their concentrations $(0.93-1.29 \mu \mathrm{g} / \mathrm{L})$ is registered in the water of the Ural River, but it does not correspond to the standards for fisheries management water bodies [38].

Our results indicate that $100 \%$ of this toxicant is present in the tissues of all fish taken for analysis. These data are an indicator that the river's water ecosystem is contaminated with a highly toxic PCB compound. In the muscles of a representative of peaceful fishbenthophage of Abramis brama, the level of accumulation of PCBs was up to $316 \mu \mathrm{g} / \mathrm{kg}$, a pike perch and an asp-from 102 to $140 \mu \mathrm{g} / \mathrm{kg}$.

The main reason for the contamination of the Ural River with PCBs is the waste input into river systems from numerous industrial enterprises, located mainly in the territory of the Russian Federation. There are huge contamination sources of the natural environment. According to research and inventory data $[39,40]$ in the South Ural region, which tends to the river basin, there are 74.5 thousand large PCB-containing equipment (transformers and capacitors). The total number of PCBs in the Orenburg, Chelyabinsk, Sverdlovsk regions and Bashkortostan is 3354 tons. Due to these huge by PCB contaminated areas the level of load of PCB-containing effluents and emissions to the atmosphere in the upper and middle parts of the Ural River basin becomes clear.

However, the possibility of river contamination within the cities of Uralsk, Atyrau, as well as Aktobe and Alga is not excluded. According to the materials of the state monitoring, in 2016-2018, the Ural River water at the territory of Kazakhstan was characterized as «moderately contaminated» (Combined Water Pollution Index (CIWP) 1.1-3.0) through the presence of heavy metals, nitrogen compounds, etc. Consequently, the level of river contamination does not decrease [41].

The Elek River is a tributary of the Ural River on the territory of Kazakhstan, which contributes significantly to its contamination. The water of the Elek River is contaminated with sewage and various wastes from ore processing enterprises in the cities of Aktobe and Khromtau. It is one of the most contaminated water courses. It is included in the priority list of water bodies of the Republic of Kazakhstan that require priority implementation of water protection measures. 
Under the influence of contaminated effluents, the water salinity in 2010 and 2012 in the area of Alga city reached 1225 and $1503 \mathrm{mg} / \mathrm{L}$. From the heavy metals in river water, the highest content is characteristic for hexavalent chromium up to $181 \mu \mathrm{g} / \mathrm{L}(9.2 \mathrm{MPC})$, copper 46-47 $\mu \mathrm{g} / \mathrm{L}$ (46 and $47 \mathrm{MPC}$ ) [c.f. Table 1].

Lead exceeds the MPC level in maximum concentrations from 21 to 27 times $(210-270 \mu \mathrm{g} / \mathrm{L})$, with an average of 6.5 to 9.9 times $(65-99 \mu \mathrm{g} / \mathrm{L})$. The results of calculations of the complex index of contamination, water of the Elek River in its entirety are classified as «Highly contaminated» and «Extremely high contaminated» [41].

According to the analysis of RSE (Republic State Enterprise) «Kazhydromet», the quality of river water in 2016-2018 corresponded to a «high level of contamination» (CIWP 3.1-10.0). Thus, there is a tendency to increase the level of river contamination [42].

\subsection{Ecological Conditions of the Caspian Sea}

The Caspian Sea is the largest inland, cross-border international water body lapping the shores of five Caspian states. It is also the recipient of a huge volume of runoff from many rivers that carry various contaminants into the world largestinland lake. The uniqueness of the Caspian Sea as the world's largest habitat for sturgeon species of fish and marine mammals, the endemic of this reservoir-the Pusa caspica, brings its problems not only to the interstate, but also to the global level.

According to the nature of the underwater terrain, the Caspian Sea is sharply divided into three parts: North, Middle and South. They are almost equal in area, but they are very different in water volume. The northern part accounts for about 1/100 of the total water volume, the middle part $1 / 3$ and, and the southern part $2 / 3$. The northern Caspian Sea, in turn, is divided into two parts: the eastern and western, the border between which runs along the line connecting Kulaly Island with Novinsky one, i.e., the eastern part of the Northern and Middle Caspian is completely located in Kazakhstan (Figure 7).

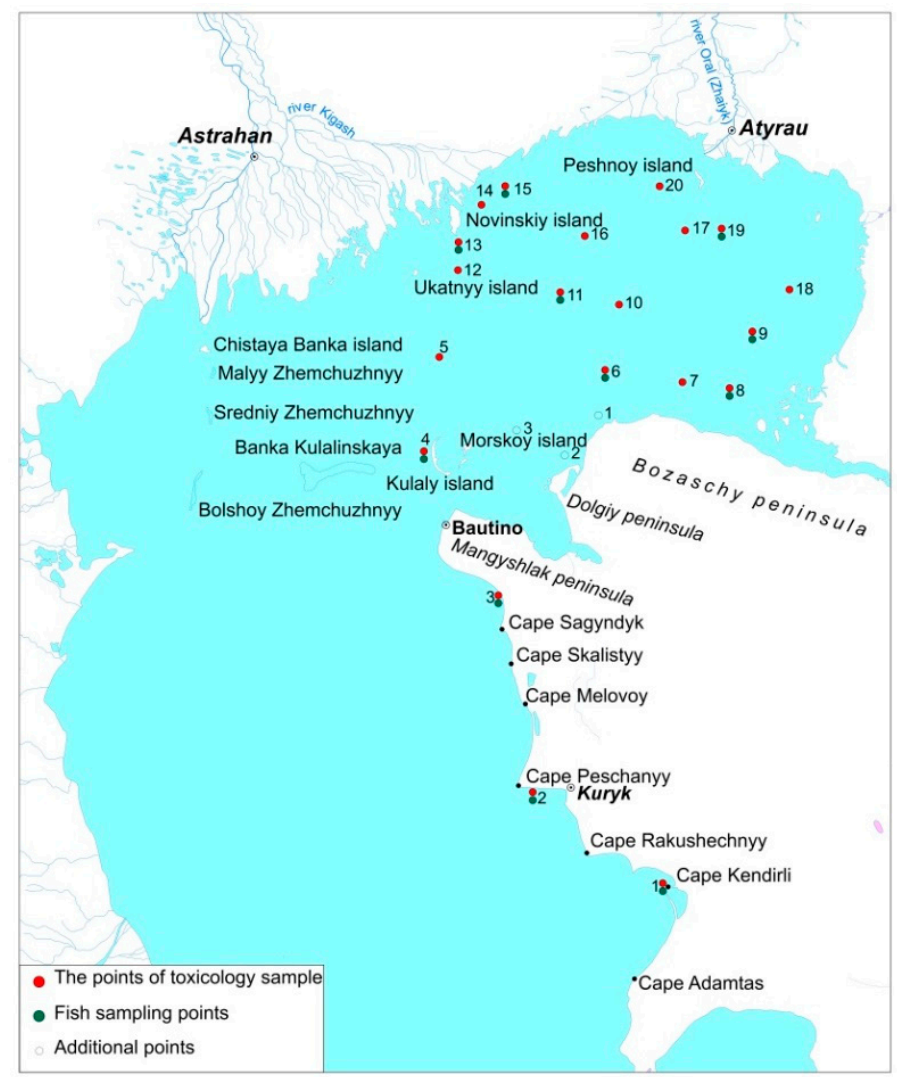

Figure 7. Kazakh part of the Caspian Sea with environmental observation stations (Source: [52]). 
The length of the coastline of the Kazakh coast is $2320 \mathrm{~km}$ or $39 \%$ of the total coastline of the Caspian Sea, equal to $5970 \mathrm{~km}$. Kazakhstan's sector is located on the shelf, in a relatively shallow zone with depths of mostly 4-8 m. Shallow water, small water volume, and a limited level of hydrodynamic processes are reasons for low intensive self-purification processes in this water body. It is 8 times slower than in the deep-water bodies of the Middle and Southern Caspian Sea. The average depth of the northern Caspian Sea and the area of its water surface significantly depend on water level fluctuations, the scope of which was $3 \mathrm{~m}$ in the 20th century. At the sea level-28.0 $\mathrm{m}$ b.s.l., the average depth of the northern Caspian is $4.5 \mathrm{~m}$. The area of the water surface is 90 thousand $\mathrm{km}^{2}$, and the water volume $397 \mathrm{~km}^{3}$. At a level-27.0 m b.s.l, close to, the area of the Northern Caspian is $105,000 \mathrm{~km}^{2}$, and the water volume is $442 \mathrm{~km}^{3}$ [43].

In terms of biological productivity, the Northern Caspian Sea is the second largest water body in the world (after the Azov Sea). A highly productive photosynthesis activity of the phytocenosis has formed a natural habitat with a powerful food base for fish and animals. Thus, there are special natural conditions in this flat water body that are most sensitive to external influences. In comparison with the rest of the deep-Caspian Sea part, the negative impact of toxic compounds there is many times stronger $[43,44]$.

Currently, under the influence of a number of powerful anthropogenic factors, the water body is being destabilized. The contamination sources of the Caspian Sea are diverse, and they are spread on the territories of all Caspian states, including their water bodies.

The development of oil and gas fields in the Caspian region is currently taking place at an increasing pace. This causes contaminations of the lake water with oil products and their accompanying toxic compounds. Under these influences the influx of contaminants along the Volga and Ural Rivers, as well as some other anthropogenic factors, the Caspian Sea water body has been destabilized.

Rivers are the main source of oil contamination in the Caspian Sea. They carry 75,000 tons/year oil products to the Caspian Sea, according to the Caspian Thematic Center for Contamination Control (Baku) [44]. This is $47.0 \%$ of the total amount of hydrocarbon contamination entering the lake. $95.5 \%$ (71,600 tons/year) of the river flow of petroleum hydrocarbons is provided by the Volga River. Part of the Volga runoff extends to the East, largely determining the background concentration of toxicants in the North-Eastern Caspian Sea. The annual flow of petroleum products from the Ural River is 900 tons/year, i.e., $1.2 \%$ of the total river flow of petroleum products to the Caspian Sea. The second largest source of contamination is the industrial runoff $(27.0 \%)$.

In particular, the rivers draining the Caucasus Mountains make a significant contribution to the oil contamination of the Caspian Sea. The average flow of petroleum products to the Caspian Sea was 0.98 thousand tons/year from the Terek River and 0.44 thousand tons/year from the Sulak River [45] in 1978-2007.

The main amounts of oil products river inflow to the Northern Caspian Sea belongs to the share of the river Volga. The volume of oil products transported by this river to the Caspian Sea varies significantly over the years.

According to various estimates, it ranges from 13 thousand tons/year to 76.7 thousand tons/year [46-48]. It is shown that the content of petroleum hydrocarbons in the water of the Northern Caspian Sea ranged from 1 to $46.6 \mathrm{MPC}(50-2330 \mu \mathrm{g} / \mathrm{L})$ on average $4.8 \mathrm{MPC}$ $(240 \mu \mathrm{g} / \mathrm{L})$ in 2002 . They become mainly concentrated both in the Western Volga passage, on the border to the Middle Caspian Sea and in the mouth of the Volga and the Ural Rivers. According to the Caspian Fisheries Research Institute [49], concentrations of petroleum hydrocarbons in the northern Caspian Sea were 0-0.62 mg/L in April 2002. On average, the Caspian Sea's hydrocarbon contents in water exceeded the average annual level by 1.8 times in 2005 [50], which corresponds a steady trend of growing petroleum hydrocarbon concentrations throughout the Caspian Sea, including in the Kazakh sector.

The problem of oil contamination of the Caspian Sea has become particularly acute and topical in connection with the large-scale development of hydrocarbon resources along the shelf of the Caspian Sea. 
It has been established that for every 1 million tons of oil produced in the world, an average of 131.4 tons of losses occurs [49]. With the specified volume of oil production, only in the water area of the Kazakh sector, about 8.0 thousand tons of oil can potentially be spilled annually. Thus, a large-scale development of oil and gas fields in the most productive Northern Caspian region is associated with an environmental risk. Studies have shown that even low concentrations of oil in water, below the maximum permissible $(0.05 \mathrm{mg} / \mathrm{L})$, lead to serious loss of functions of important organs of aquatic animals [33,38,39].

\subsubsection{Contamination by Petroleum Hydrocarbons}

According to the results of our joint research with «Biomedpreparat» LLP, in the Kazakhstan sector of the Caspian Sea, the concentration of petroleum hydrocarbons in Caspian Sea water exceeded the level of fisheries management MPC from 2 to 23 times in 2008; both in 2009 and 2010 up to 16 and 21 times (0.8-1.05 mg/L), respectively, respectively. The maximum concentrations of these contaminants are recorded in the Casipian Sea water affected by the inflow of the Volga River and the Ural River, as well as in areas of active oil fields, such as Tengiz, Kalamkas, Karazhanbas, etc. (Figure 8) [51,52].
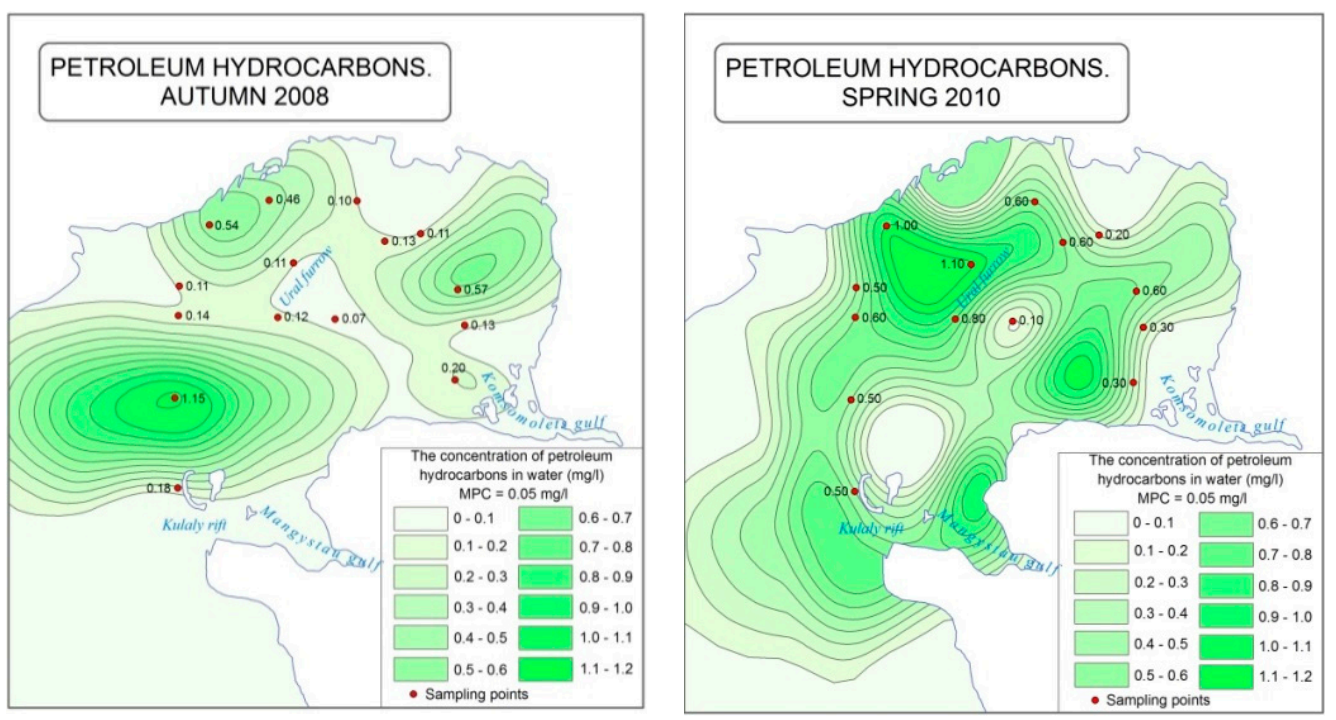

Figure 8. Water concentrations and distribution of petroleum hydrocarbons in the eastern part of the Northern Caspian Sea.

Fairly high levels of petroleum hydrocarbon, organochlorine pesticide, and heavy metal accumulation in the muscles of marine fish were detected during the period of comprehensive research within the Kazakh sector of the Caspian Sea in 2008-2010. The concentration of petroleum hydrocarbons in the muscles of fish varied in the range from 2.4 to $216 \mathrm{mg} / \mathrm{kg}$ in 2008, from 2.3 to $513 \mathrm{mg} / \mathrm{kg}$ in 2009. The concentration of contaminants in the muscle of sturgeon fish reached $200-363 \mathrm{mg} / \mathrm{kg}$, and in muscular tissues of herring $212-264 \mathrm{mg} / \mathrm{kg}$.

From Cyprinidae breeds, the maximum accumulation of this contaminant was up to 107 and $216 \mathrm{mg} / \mathrm{kg}$ for Abramis brama, and up to 332 and $513 \mathrm{mg} / \mathrm{kg}$ for Caspian roaches [53,54]. For petroleum hydrocarbons, sanitary standards of the maximum permissible level (MPL) in fish have not been developed yet. Figure 9 shows the fishing points and the concentration of petroleum hydrocarbons registered in the muscle tissue of Acipenser gueldenstaedtii and Alosa brashnikovii fish species in this zone [55]. The illustration shows that the highest level of accumulation of petroleum hydrocarbons is registered in Acipenser gueldenstaedtii caught in water east of the Ural River mouth and in the Kulalynskiy deep water zone. This may be due to increased oil contamination of water and feed facilities in these areas. Also, their concentration in muscles of fish species in the Eastern and South-Eastern sections of the 
Northern Caspian Sea is increased, which indicates the increased contamination of these parts of the Caspian Sea with these toxic compounds.
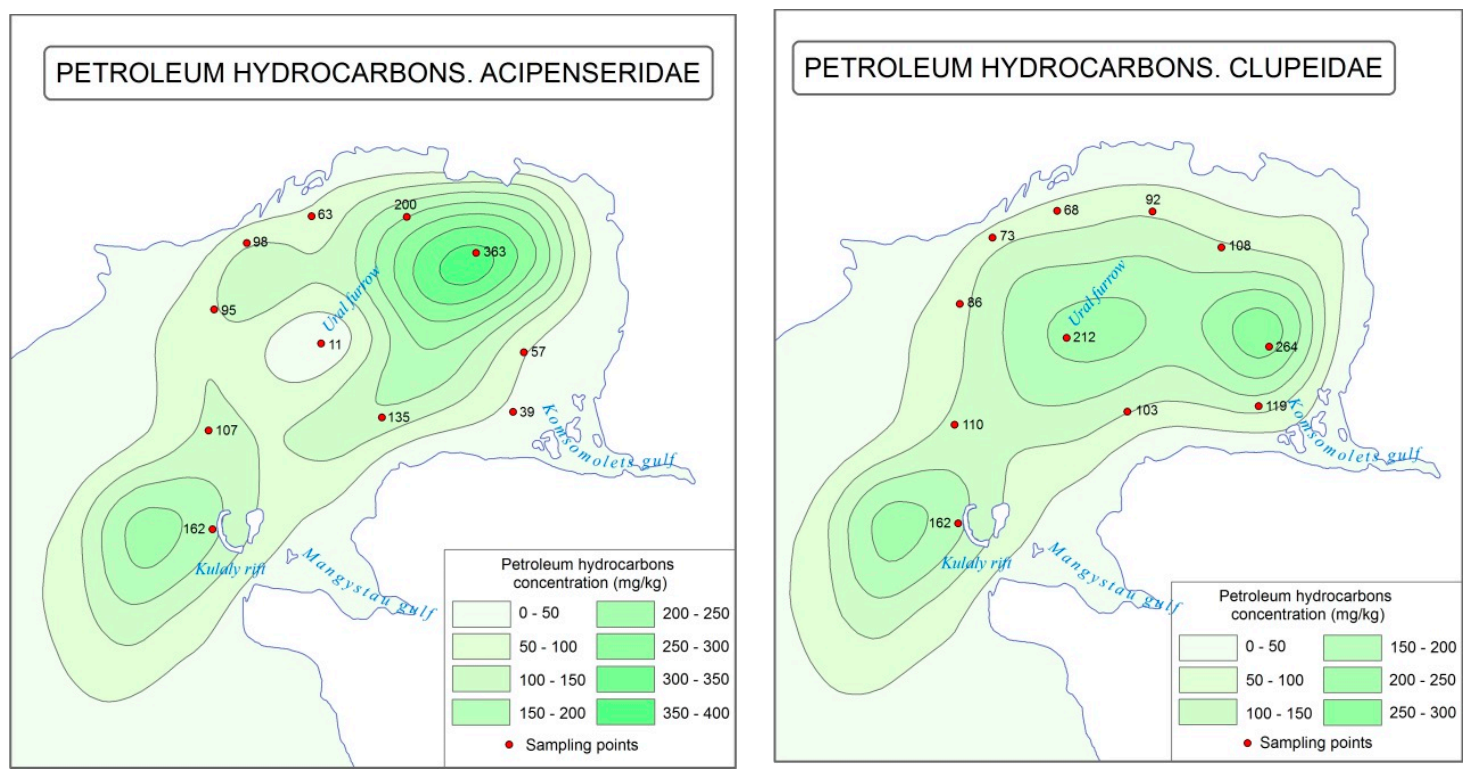

Figure 9. Petroleum hydrocarbon concentrations in the muscular of Acipenseridae and Clupeidae fish species in the north-eastern section of Caspian Sea.

According to the analytical data obtained from representatives of the ichthyofauna of the Kazakh sector of the Caspian Sea sequences of descending concentration of petroleum hydrocarbons in the muscle tissue have been detected: Rutilus rutilus, Acipenser gueldenstaedtii, Alosa brashnikovii, Abramis brama, Acipenser stellatus, Aspius aspius, Sander volgensis, Abramis sapa, Acipenser ruthenus, Cyprinus carpio, Sander lucioperca. The results of the study also suggest that the Cyprinidae (Rutilus rutilus and Abramis brama) are promising accumulative bioindicators of contamination of the water ecosystem of the Caspian Sea with oil-based hydrocarbons [53,55].

\subsubsection{Heavy Metal Contamination}

Studies conducted in 2003-2005 and 2008-2010 showed the presence of a range of heavy metals such as copper, zinc, nickel, etc. in the Caspian Sea water, their concentrations exceeding the regulatory limits $[56,57]$.

The concentration and distribution of metals in the area of the Ural River inflow are characterized by a high variability from year to year. During spring 2005, the content of $\mathrm{Cu}, \mathrm{Ni}, \mathrm{Co}, \mathrm{Cd}$, and $\mathrm{Cr}$ decreased in comparison with 2003. The other elements increased slightly (Figure 10). The inter-annual and seasonal differences of metal concentrations in the Caspian Sea water are a result of different ratios of fresh river water and both brakish and salty lake water at sampling points, which in turn depends on both wind direction and river flow, and the sedimentation of river sediments in this transition zone. The concentration of heavy metals in the water of this zone, except cadmium, exceeds the MPC level.

The Casian Sea water east from Ural River mouth in 2003-2005 was characterized by higher metal concentrations in comparison with the transition zone between the Volga River and the Ural River. The deep water zone in the South-East of the pre-estuary coast of the Ural River, was characterized by increased metal concentrations during the same time.

Our own studies in 2007, covering the southern coast of the eastern part of the Northern Caspian Sea and the eastern coast of the Middle Caspian Sea, showed significant increase of copper concentrations in the water in the direction to Cape Sarzha up to $14.2 \mu \mathrm{g} / \mathrm{L}$, i.e., 2.8 MPC for Caspian Sea water (c.f. Table 1). 


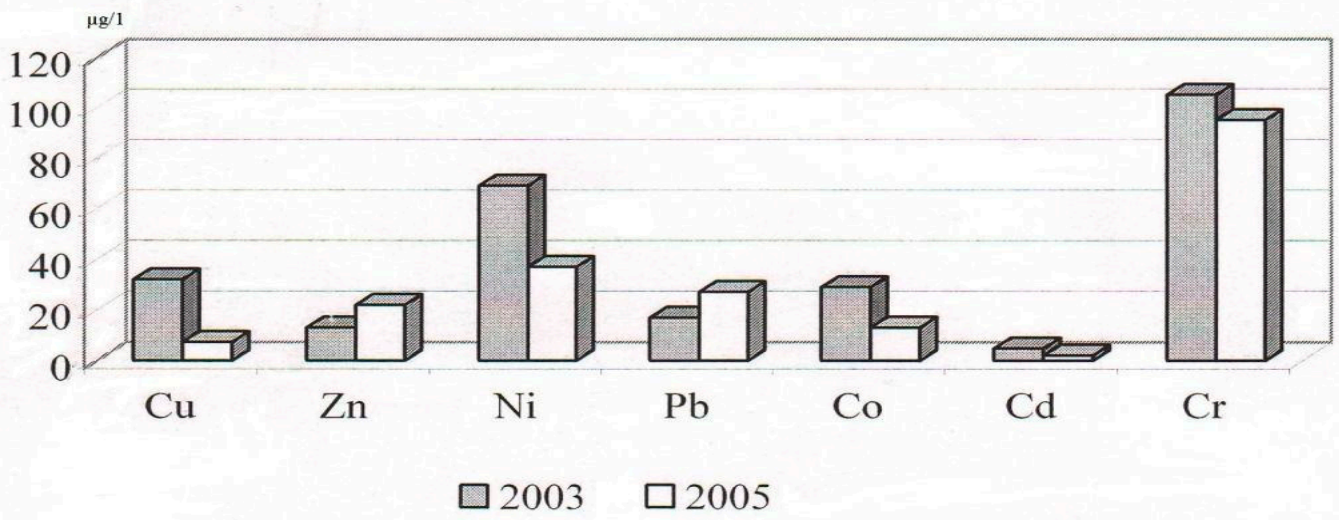

Figure 10. Average heavy metal concentrations in water of the pre-estuary coast of the Ural River.

More detailed information on the distribution of heavy metals across the entire water area of the Kazakh sector of the Caspian Sea was obtained in 2008-2010. The analytical material is presented in Table 2 . The data indicate a large concentration variability of the analyzed metals in the space-time relation.

Table 2. Average heavy metal concentrations in water of the Kazakh sector of the Caspian Sea, in $\mu \mathrm{g} / \mathrm{L}$.

\begin{tabular}{ccccc}
\hline Sampling Time & $\mathbf{C u}$ & $\mathbf{Z n}$ & $\mathbf{P b}$ & $\mathbf{C d}$ \\
\hline 2008, August & 22 & 34 & 3.5 & 4.7 \\
\hline 2009, May & 20 & 25 & 31 & 6.1 \\
\hline 2009, August & 29 & 28 & 28 & 5,6 \\
\hline 2010, May & 33 & 66 & 5.3 & 2.9 \\
\hline 2010, August & 23 & 37 & 3.2 & 4.5 \\
\hline MPC & 5 & 50 & 10 & 10 \\
\hline
\end{tabular}

Figure 11 shows the average concentrations of the most priority metals in the water of certain regions of the Kazakh sector of the northern Caspian Sea in 2008-2010.

The spatial distribution of heavy metals in the water over the entire area of the northeastern Caspian Sea for the remaining seasons is more clearly shown in Figure 12 [51,57]. The illustrations above show first of all a significant difference in the concentration and distribution of metals by seasons. For zinc, copper and lead, the maximum concentrations and their wider distribution over the considered Caspian Sea area were registered in spring time. Zinc concentrations above the fishery MPC $(50 \mu \mathrm{g} / \mathrm{L})$ have been measured at almost all sampling points during the same season in 2010, while they exceed the MPC in autumn, detected only at three points located in the influence zone of the Volga River flow. 

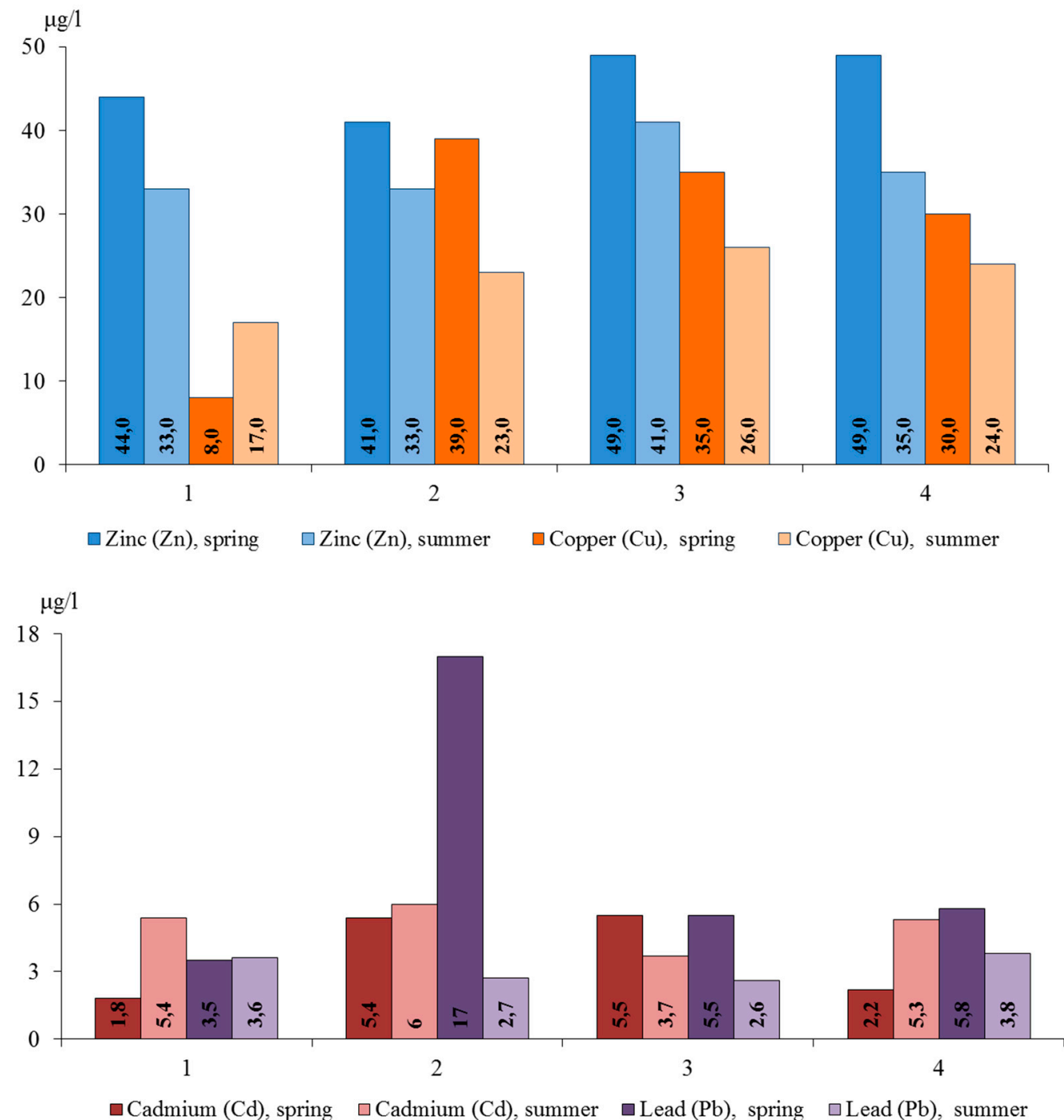

Areas: 1 -Kulalyn deep water zone, 2 - South-Eastern part of the Northern Caspian, 3 - Volga river confluence zone, 4 - Ural river confluence zone

Figure 11. Average heavy metal concentrations in water of certain areas of the north-eastern Caspian Sea.
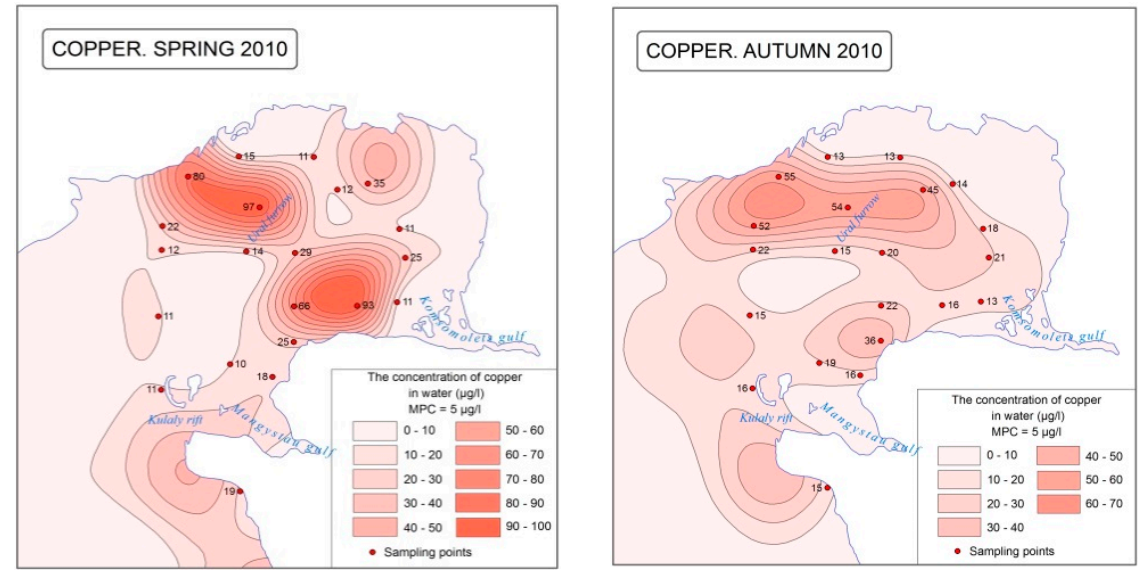

Figure 12. Cont. 

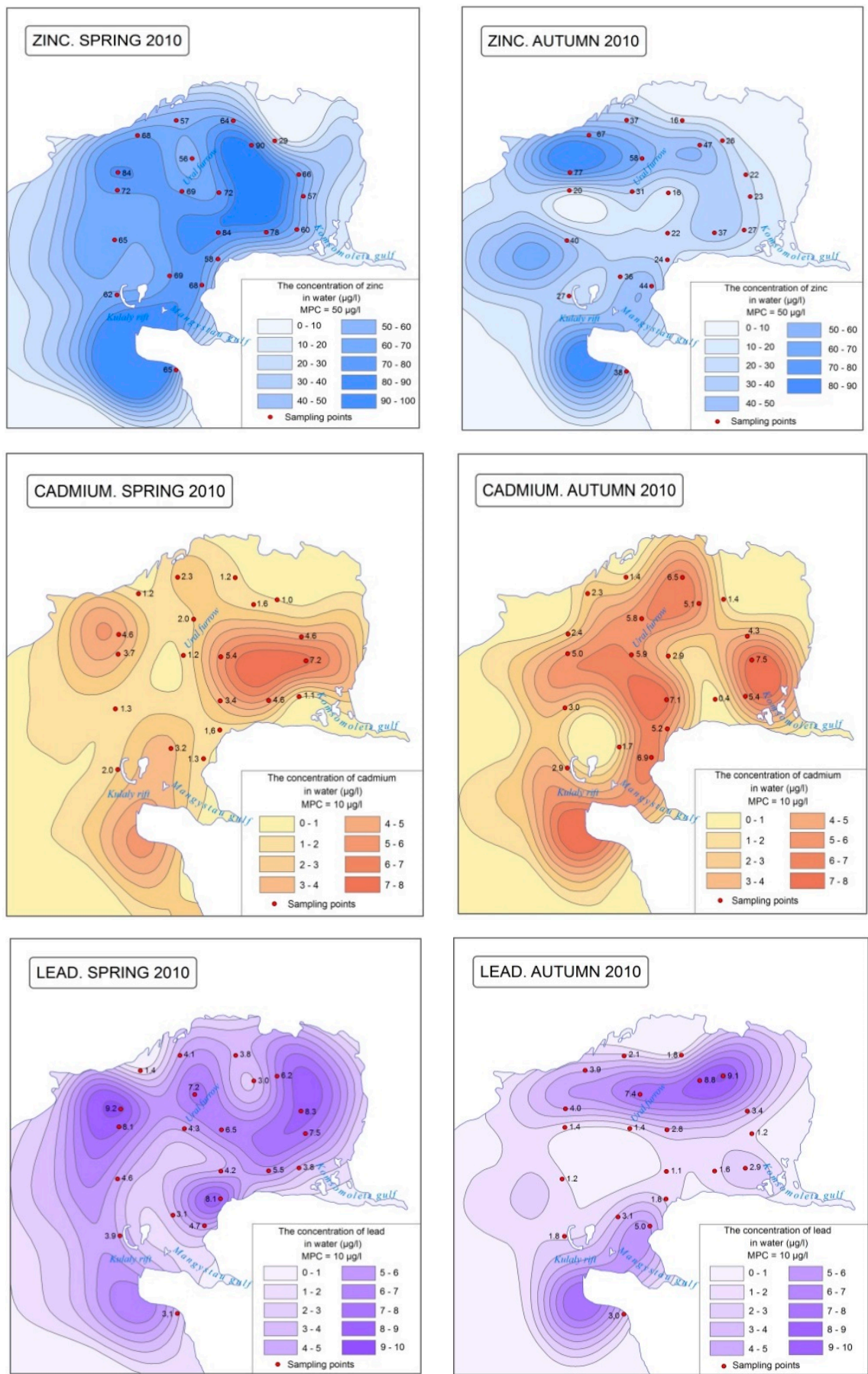

Figure 12. Spatial distribution of heavy metals in water of the north-eastern Caspian Sea.

Although the content of lead in the Caspian Sea water did not exceed the MPC $(10 \mu \mathrm{g} / \mathrm{L})$, its elevated concentrations from 7.5 to $9.2 \mu \mathrm{g} / \mathrm{L}$ were more widespread in the studied part of the Caspian Sea during spring. The over the years concentration of copper as shown in Table 2, with rare exceptions, was recorded significantly higher than the level of fisheries management MPC ( $5 \mu \mathrm{g} / \mathrm{L})$ for sea water. The cadmium concentration did not reach the MPC standards during the studied period. In contrast to zinc, copper and lead, higher concentrations of cadmium were registered mainly during the autumn period. In addition, increased concentrations of this element are more widely distributed in the Kazakhstan sector of the Caspian Sea. 
Before presenting the accumulation levels both of heavy metals and pesticides in the ichthyofauna, we consider to provide the standards that are in force for this issue (Table 3), given in a number of sources [58-60], for subsequent comparison with the obtained results.

Table 3. Maximum permissible level (MPL) of toxicants in fish food products.

\begin{tabular}{cccc}
\hline \multirow{2}{*}{ Toxic Substance } & \multicolumn{2}{c}{ Fresh Fish, $\mathbf{~ m g} / \mathbf{k g}$} & Sources \\
\cline { 2 - 3 } & Freshwater Fish & Seawater ${ }^{*}$ Fish & \\
\hline Lead & 1.0 & 1.0 & {$[57]$} \\
Cadmium & 1.0 & 2.0 & {$[58]$} \\
Arsenic & 0.2 & 0.2 & {$[57,58]$} \\
Mercury & 1.0 & 5.0 & {$[57,58]$} \\
& 0.3 & 0.4 & {$[57]$} \\
Copper & 0.3 & 0.5 & {$[58]$} \\
Zinc & 10 & 10 & {$[57,58]$} \\
HCH & 40 & 40 & {$[58]$} \\
DDT & 0.03 & 0.2 & {$[57,59]$} \\
PCBs & 0.3 & 0.2 & {$[57,59]$} \\
\hline
\end{tabular}

* Due to the fact, that there are no standards, especially for fish species in the Caspian Sea, seawater respectively marine water standards were used.

In 2003-2005, a number of priority metals were determined in the muscles and livers of Huso huso, Acipenser stellatus, Acipenser gueldenstaedtii, Acipenser nudiventris caught during the spawning period. A general pattern is revealed: for most metals and all types of Acipenseridae, there is a higher concentration of toxicants, including metals, in the liver of fish, than in the muscles (Figures 13-15). The accumulation level of the analyzed elements in the organs and tissues of Acipenseridae varies markedly over the years.
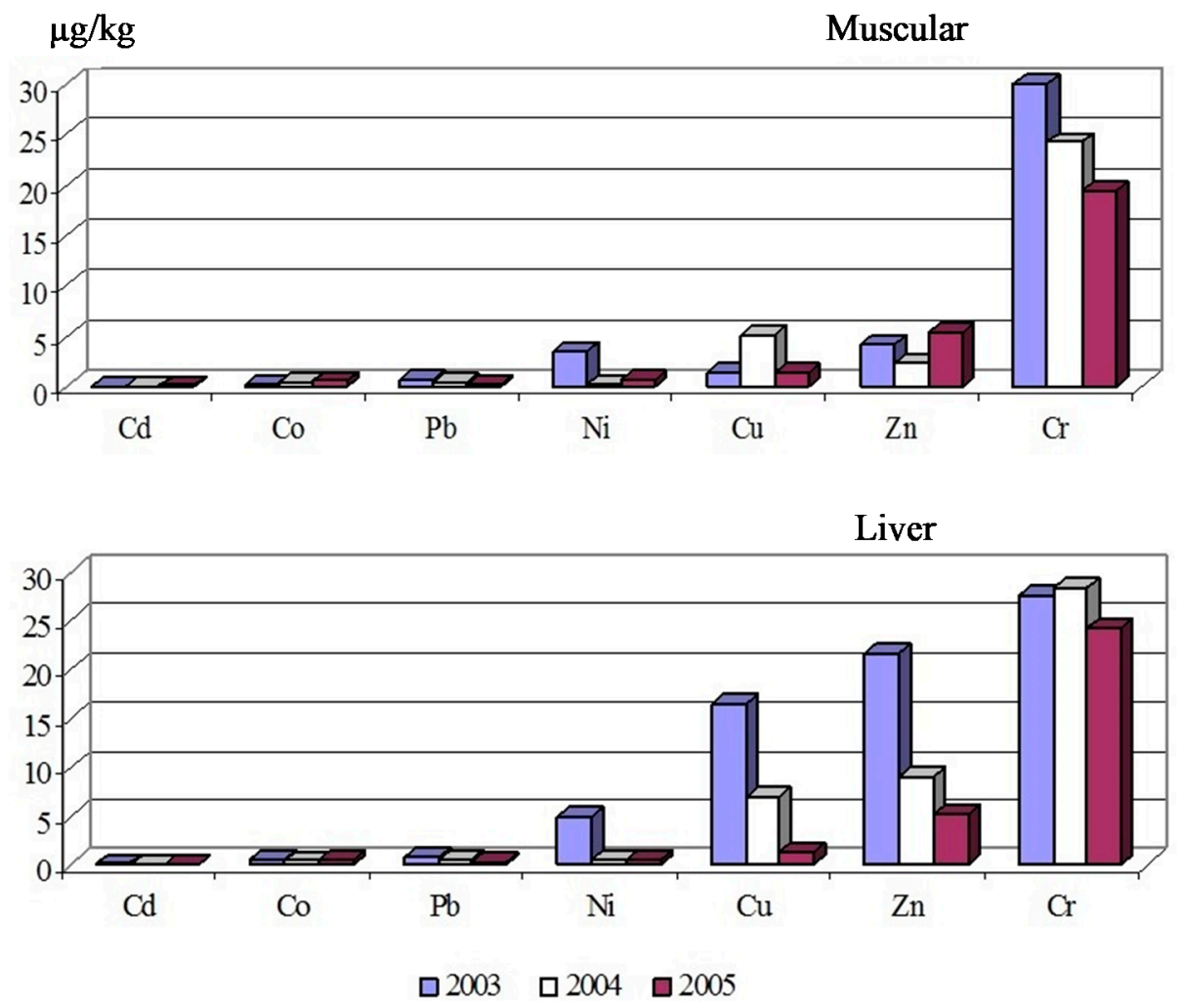

Figure 13. Heavy metal accumulation level in muscular and liver of Acipenser stellatus. 

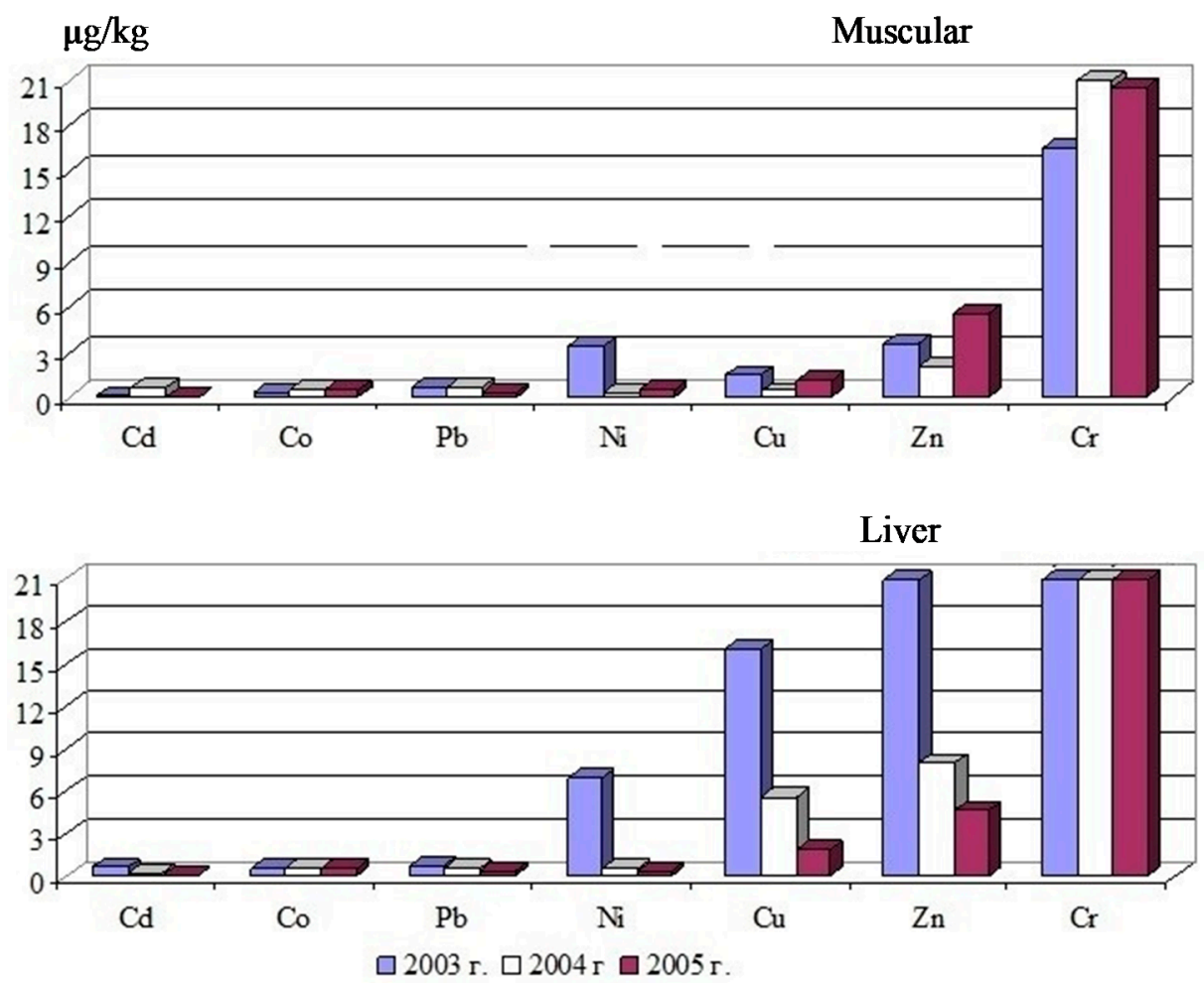

Figure 14. Heavy metal accumulation level in muscular and liver of Acipenser gueldenstaedtii.

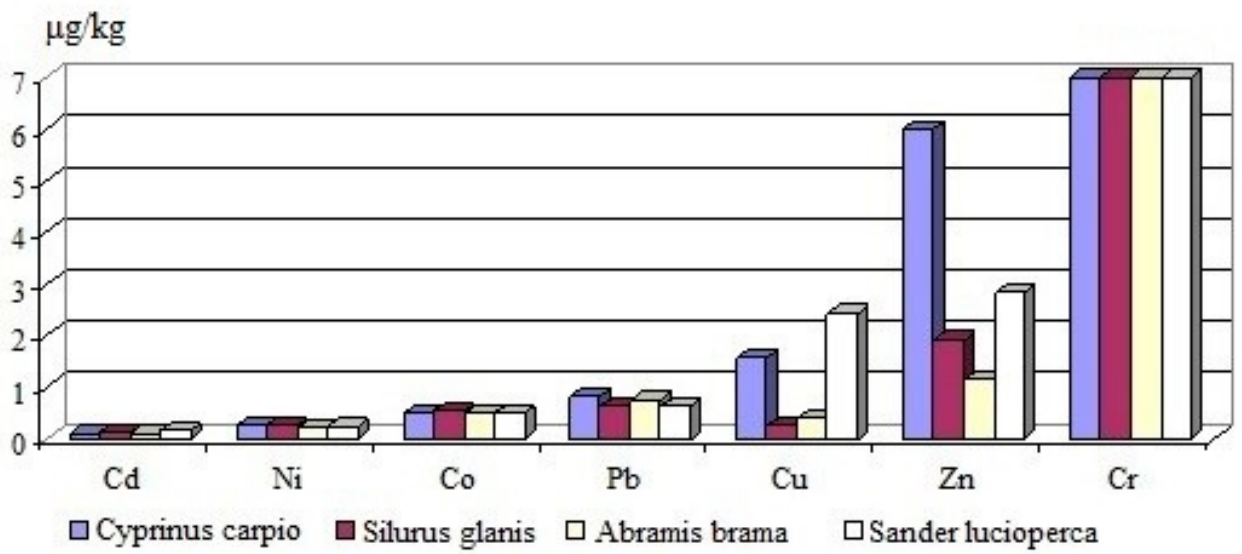

Figure 15. Heavy metal accumulation level in muscular of small fishes from the north-western desalinated zone of the Caspian Sea.

It is known that individual metals have a different ability to accumulate in the organs and tissues of aquatic organisms $[10,14,55,58]$. Analysis of the metal ratio series by the level of their concentration in the organs of certain species of studied fish in general shows their similarity.

Based on the obtained material, the following most characteristic series of metals were identified in descending order of their concentration for Acipenser gueldenstaedtii muscular tissue $\mathrm{Cr}>\mathrm{Zn}>\mathrm{Cu}>\mathrm{Pb}>\mathrm{Co}>\mathrm{Ni}>\mathrm{Cd}$, and for the liver of these fishes $\mathrm{Cr}>\mathrm{Zn}>\mathrm{Cu}>\mathrm{Ni}>\mathrm{Pb}>\mathrm{Co}>\mathrm{Cd}$.

The composition of more active migrants, consisting of three elements $(\mathrm{Cr}, \mathrm{Zn}, \mathrm{Cu})$ is constant in the liver and muscles. Cobalt and lead accumulate more actively in the muscles, and nickel in the liver.

The results of the metal analyses in the muscles of small fishes, caught in the northwestern desalinated zone of the Caspian Sea, showed a similar level of metal concentrations 
in the muscle tissues of all fish species taken for analysis. The Cyprinus carpio caught in the shallow zone had maximum concentrations of lead $(1.01 \mathrm{mg} / \mathrm{kg})$ and zinc $(8.36 \mathrm{mg} / \mathrm{kg})$ in the muscles.

Comparing these results with the standard values (Table 3), the accumulation of most metals is lower than the MPL. Only in the muscles of carp from the shallow zone, the concentration of lead reaches the standard level.

In 2008-2010, during complex ecological expeditions and investigations, the accumulation of a number of heavy metals in the organs and tissues of fish from the open part of the Kazakh sector of the Caspian Sea was studied. The results obtained are generally consistent with the above mentioned data for 2003-2005.

The level of heavy metal accumulation is generally uneven both in the water area of the north-eastern part of the Caspian Sea and in fish species. At certain points of the lake, there is a higher accumulation level, which is 10,19 and $23 \mathrm{mg} / \mathrm{kg}$ for Acipenseridae, Clupeidae and Rutilus rutilus, respectively. The maximum accumulation of zinc was detected in Acipenseridae and Rutilus rutilus caught in the south-eastern section of the Northern Caspian Sea, i.e., in areas of active use of oil and gas fields. This is shown in Figure 16 as an example for the roach.
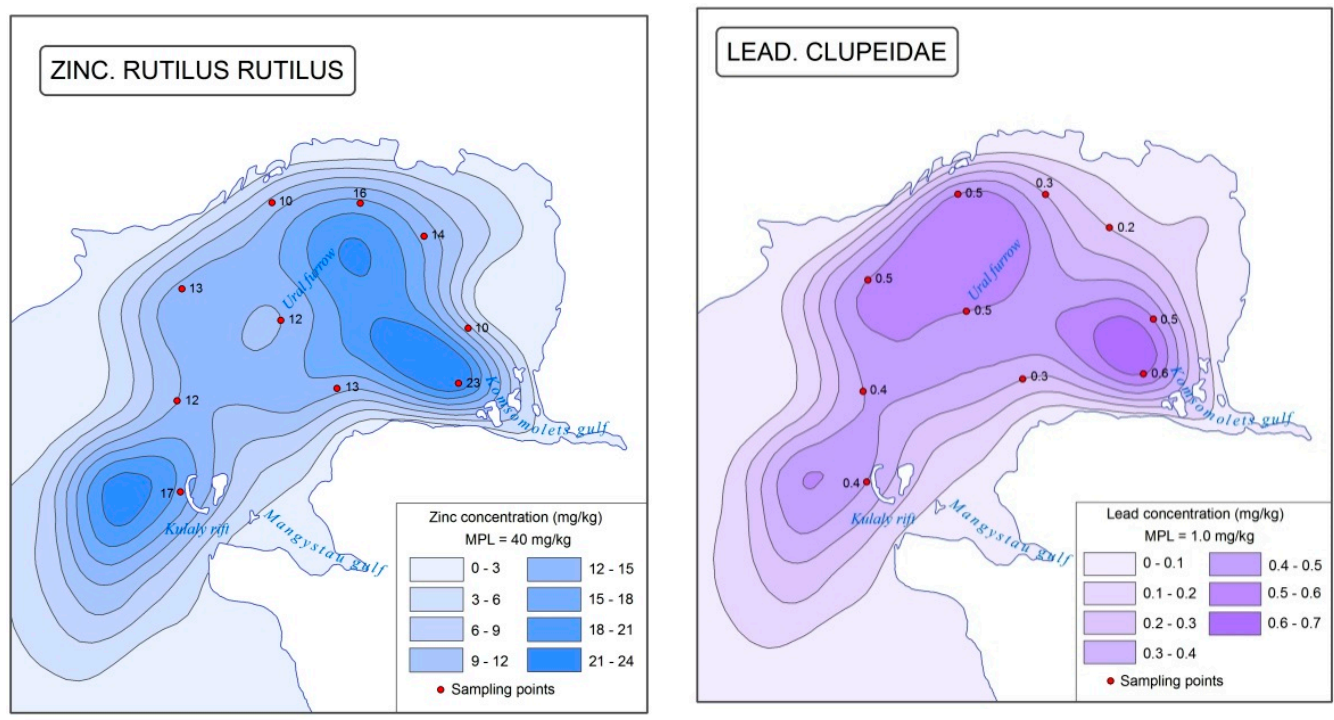

Figure 16. Zinc and lead accumulation levels in muscular of fish species in certain parts of the north-eastern Caspian Sea.

Cadmium accumulates in tissues in a low amount. $20 \%$ of Acipenseridae and $50 \%$ of Rutilus rutilus of all the samples taken did not contain cadmium; its content in the muscles of all studied fish species varied from 0.1 to $0.3 \mathrm{mg} / \mathrm{kg}$, in a single case-up to $0.6 \mathrm{mg} / \mathrm{kg}$.

The presence of lead was registered in all samples taken for analysis. Its concentration in fish muscles varies within narrow limits: in Acipenseridae and Rutilus rutilus $0.2-0.5 \mathrm{mg} / \mathrm{kg}$ and $0.2-0.7 \mathrm{mg} / \mathrm{kg}$, respectively, in Clupeidae $0.3-0.8 \mathrm{mg} / \mathrm{kg}$. The highest accumulation of lead is recorded in the muscles of fish species in strong contaminated areas of the Caspian Sea. The distribution pattern for Clupeidae is shown in Figure 16.

The analysis of the presented illustrations clearly shows that the characteristic feature of the distribution of all the considered elements is the increased accumulation in certain parts of the considered Caspian Sea area. Namely, in the areas affected by the flows of the Volga River and Ural River, in the south-eastern part, where a number of large oil and gas field facilities are located, as well as in the zone of the Kulalinskiy threshold, by which the contaminated water mass, in the direction to the Caspian Sea current characteristics for this section, spreads towards the Middle Caspian Sea. A similar pattern of distribution in this lake area is typical for other toxic compounds, including petroleum hydrocarbons, as mentioned above. 
The water quality of the Kazakh sector of the Caspian Sea, according to the state monitoring in recent years, is characterized by different levels of contamination from «Standard-clean» to «Moderately contaminated».

\subsubsection{Pesticide Contamination}

According to the results of studies [52,61], organochlorine pesticides-metabolites of DDT and isomers of $\mathrm{HCH}$ are registered in the water of the Caspian Sea. In the northeastern Caspian Sea in 2003-2005, HCH isomers were found in all analyzed samples, but their concentration is low. The most contaminated section with pesticides is the northwestern zone of the Kazakh sector, which is under the influence of the Volga River inflow. More elevated concentrations of DDT metabolites in 2004 were registered in the water between the Volga River and the Ural River. During spring 2005 the content of pesticides was decreased compared to previous years. The main results obtained in 2008-2010 are presented in Table 4.

Table 4. Average pesticide concentrations in the Caspian Sea water, in $\mu \mathrm{g} / \mathrm{L}$.

\begin{tabular}{ccc}
\hline Period & Northern Caspian Sea & Middle Caspian Sea \\
\hline Spring, 2008, 2009, 2010 & 0.59 & \\
\hline Summer, 2008, 2009, 2010 $(\alpha, \gamma)$ & 0.35 \\
\hline Spring, 2008, 2009, 2010 & 0.12 & 0.08 \\
\hline Summer, 2008, 2009, 2010 & DDT (4.4 и 2.4) & 7.82 \\
\hline
\end{tabular}

Attention is drawn to the presence of DDT metabolites in the water of the entire surveyed Caspian Sea area. Their concentrations are quite high in spring, up to $14.20 \mu \mathrm{g} / \mathrm{L}$ and in summer up to $22.48 \mu \mathrm{g} / \mathrm{L}$. The analysis of the spatial distribution of $\mathrm{HCH}$ and DDT allows us to identify three areas where increased concentrations of these pesticides were registered.

First: the Caspian Sea area affected by the inflow of the Volga and Ural Rivers, where increased concentrations were recorded only in spring of $\mathrm{HCH} 1.11-2.0 \mu \mathrm{g} / \mathrm{L}$, DDT 7.80-49.80 $\mu \mathrm{g} / \mathrm{L}$.

The second sector covers the southern and south-eastern section of the Northern Caspian Sea. In this zone, the maximum concentrations of $\mathrm{HCH} 1.70$ and $2.08 \mu \mathrm{g} / \mathrm{L}$ were recorded in spring, and DDT metabolites during summer and spring in the range of 7.00-22.48 $\mu \mathrm{g} / \mathrm{L}$. According to specialists of Caspian Fisheries Research Institute [50], the presence of local areas with increased concentrations of pesticides is a consequence of the atmospheric transport and dynamic dispersion. The increase in the concentration of pesticides in the water of this zone can also be explained by the fact that it tends to be geographically to the Kulalinskiy deep water area, within which there is an active sedimentation and deposition of a significant proportion of airborne toxic materials in the convergence of water streams from the eastern and western parts of the Northern Caspian Sea.

The third area is the eastern coast of the Middle Caspian Sea near the border of Turkmenistan, where DDT concentration reached 9.10-10.8 $\mu \mathrm{g} / \mathrm{L}$. The presence of DDT and $\mathrm{HCH}$ in the water of this area was also revealed by the research of the Caspian Fisheries Research Institute. These facts are explained by the authors both by the arrival of pesticides with drainage drains and dry and wet depositions from the atmosphere.

Thus, our research has determined the facts of continuing pesticide contamination of the Caspian Sea at the present time, despite the fact that the use of these classes of pesticides in agriculture has been prohibited long time before. The impact of these contaminants of high potential toxicity into both the tributaries and the Caspian Sea waters is probably 
due to their high resistance to biodegradation and a long half-life especially under the dry conditions of the semi-arid and arid climate of the northern and eastern Caspian Sea areas, which, according to various authors, ranges from 7 to 38 years. Therefore, experts conclude that the water contamination by pesticides is and will be still a great danger [62].

In 2004-2005, we subjected small fish and sturgeon to toxicological analysis. The results are presented in Table 5 .

Table 5. Pesticide accumulation in muscles and liver of Acipenseridae species in 2004 and 2005.

\begin{tabular}{|c|c|c|c|c|c|c|}
\hline \multirow{4}{*}{ Species of Fish } & \multicolumn{2}{|c|}{2004} & \multicolumn{4}{|c|}{2005} \\
\hline & $\mathrm{HCH}$ & DDT & \multicolumn{4}{|c|}{ HCH (Isomers) } \\
\hline & \multicolumn{2}{|c|}{ Muscle } & \multicolumn{2}{|c|}{ Muscle } & \multicolumn{2}{|c|}{ Liver } \\
\hline & \multicolumn{2}{|c|}{$\mu \mathrm{g} / \mathrm{kg}$} & $\mu \mathrm{g} / \mathrm{kg}$ & Occurrence \% & $\mu \mathrm{g} / \mathrm{kg}$ & Occurrence \% \\
\hline Acipenser stellatus & Not up & $0.0-40$ & $0.0-1.60$ & 25 & $0.0-2.0$ & 37 \\
\hline $\begin{array}{c}\text { Acipenser } \\
\text { gueldenstatedtii }\end{array}$ & Not up & Not up & $0.0-2.00$ & 60 & $0.0-2.0$ & 60 \\
\hline Huso huso & Not up & 10.0 & $1.0-2.0$ & 100 & $0.0-1.2$ & 50 \\
\hline Acipenser nudiventris & & & $0.0-1.70$ & 75 & $0.0-2.80$ & 50 \\
\hline $\mathrm{MPL}, \mu \mathrm{g} / \mathrm{kg}$ & 200 & 200 & 200 & & & \\
\hline
\end{tabular}

In 2004, no HCH isomers were founded in the muscles of Acipenseridae species. The presence of DDT observed in the Acipenser stellatus and middle number in the muscles of the Huso huso. In spring 2005, no DDT metabolites were founded in the organs and tissues of Acipenseridae. However, the accumulation of $\mathrm{HCH}$ isomers has become more widespread, although their concentration is not as high. In the muscles of Acipenseridae the occurrence of these toxicants was in the range of $25 \%$ for Acipenser stellatus to $100 \%$ for Huso huso, in the liver from 37 to $60 \%$, the maximum is also characteristic of Huso huso, and the minimum is for Acipenser stellatus. The detected concentrations of toxicants are generally low, from 1.0 to $2.0 \mu \mathrm{g} / \mathrm{kg}$ in the fish muscles and from 1.2 to 2.8 in the liver.

Unlike Acipenseridae, the presence of $\mathrm{HCH}$ isomers and DDT metabolites was registered in the muscles of small fishes. $\mathrm{HCH}$ isomers are found in rare cases mainly in the muscles of fish caught in shallow waters adjacent to the Volga Delta. The presence of these toxicants in higher concentrations $(0.70-2.5 \mu \mathrm{g} / \mathrm{kg})$ was found mainly in the muscles of Cyprinus carpio. DDT metabolites were registered in almost all analyzed fish particles, the percentage of their occurrence was from 50 to 100. The highest concentrations of DDT were detected between 60 and $140 \mu \mathrm{g} / \mathrm{kg}$ in Cyprinus carpio, Abramis brama, and predatory species in Silurus glanis and Esox lucius.

From these data it follows that the shallow Caspian Sea area is influenced by Volga River runoff. The accumulation of pesticides in fish there is much higher than in other parts of the Northern Caspian Sea. Consequently, the increased pesticide contamination of the Volga River runoff is the reason for a fairly high accumulation of these toxicants in the organs and tissues of fish.

The organochlorine pesticides accumulation in the ichthyofauna of the Kazakh sector of the Caspian Sea, according to our research in 2008-2010, is briefly characterized by the following data. Dichlorodiphenyltrichloroethane (DDT) at the highest level between $369 \mu \mathrm{g} / \mathrm{kg}$ and $449 \mu \mathrm{g} / \mathrm{kg}$ was registered in the muscles of Clupeidae and Acipenseridae respectively. It accumulates in the tissues of the Rutilus rutilus-up to $40 \mu \mathrm{g} / \mathrm{kg}$ significantly less, in frequent cases it was not detected. $200 \mu \mathrm{g} / \mathrm{kg}$ DDT, that means an excess of the MPL standard for Caspian Sea fish, in three cases for Acipenseridae and Clupeidae species was detected. Maximum DDT accumulation was registered in Acipenseridae caught in the preestuary sections of the Ural River and Volga River (Figure 17). Its maximum concentration 
in Clupeidae was observed in the eastern water section, although this toxicant accumulation is at an increased level throughout the whole Northern Caspian Sea.
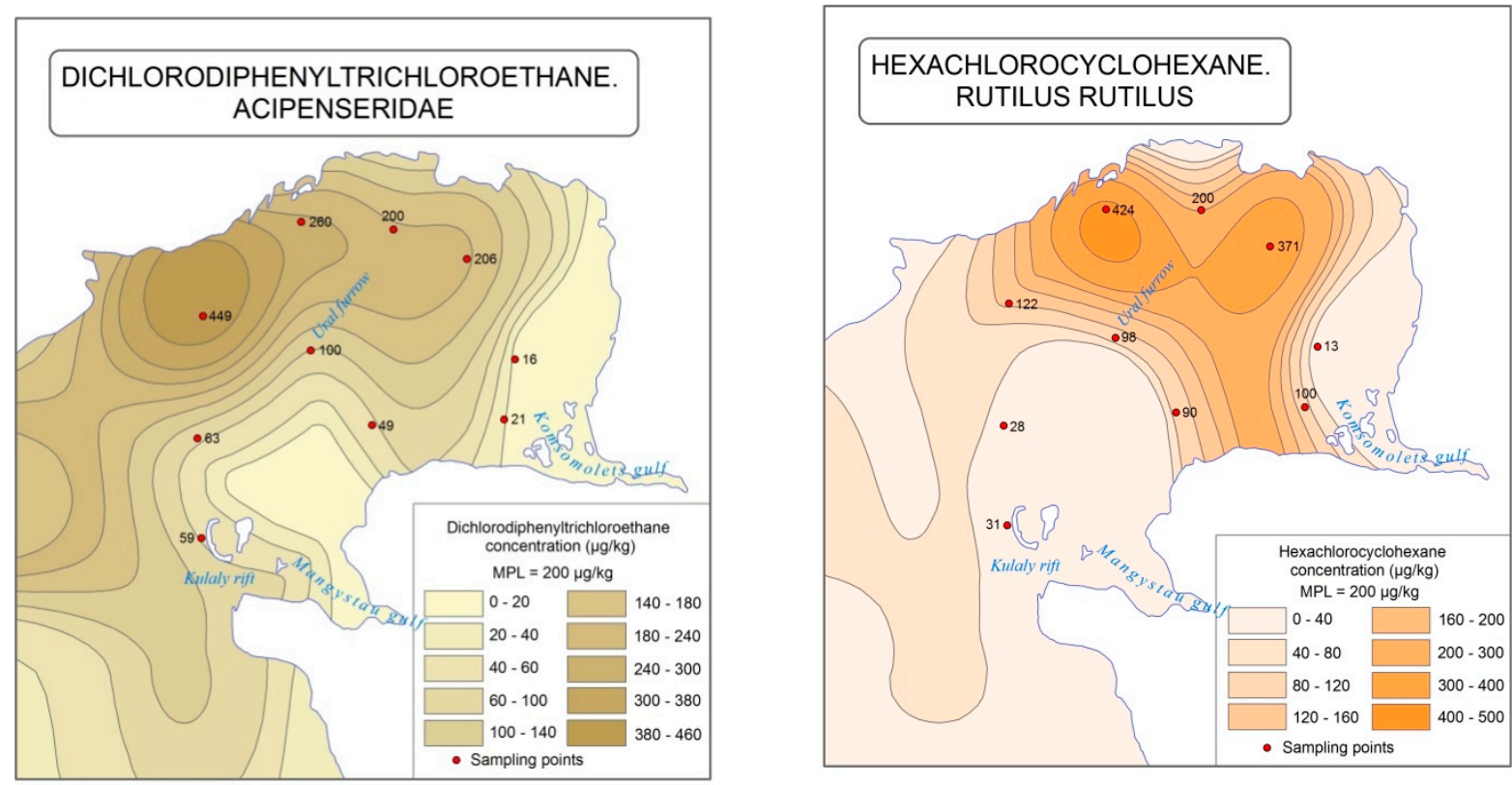

Figure 17. Organochlorine pesticides (DDT and $\mathrm{HCCH}$ ) in muscular of Acipenseridae and Rutilus rutilus fish breeds.

Hexachlorocyclohexane (HCH) was not detected in $50 \%$ of Acipenseridae and $30 \%$ of Clupeidae fish. The highest concentration of the toxicant reached $194 \mu \mathrm{g} / \mathrm{kg}$ in Acipenseridae muscles and $160 \mu \mathrm{g} / \mathrm{kg}$ in Clupeidae muscles, i.e., below the MPL. In contrast to these species, the Rutilus rutilus accumulates HCH in a higher concentration up to $371-424 \mu \mathrm{g} / \mathrm{kg}$, with $100 \%$ occurrence in all samples taken.

In Acipenseridae and Clupeidae fish species, the maximum accumulation of hexachlorocyclohexane was found in the desalinated pre-estuary zone of the Volga River, and the maximum for Rutilus rutilus was recorded in the northern coast and in the pre-estuary space of the Ural River (Figure 17). In 20\% of the analyzed Rutilus rutilus HCH was found above the normative level. DDT metabolites accumulate in fish at a higher level than $\mathrm{HCH}$, with the exception of Rutilus rutilus.

The maximum permissible level (MPL) is not a biological, but a sanitary norm established for limiting and evaluating the nutritional qualities of fish products. According to [53], the presence of these toxic compounds in reservoirs that are genetically uncharacteristic of the composition of natural waters can have a harmful effect both on hydrobionts and on human health.

The above mentioned data demonstrates that the sections of the strongest water pollution by various toxicants and their maximum accumulation in the muscles of ichthyofauna are almost identical.

Against the background of the above mentioned results on the accumulation of petroleum products, metals and pesticides in the organs and tissues of fish, a general pattern was observed: a higher concentration of metals, pesticides and other toxicants occurs in the liver in internal fat and sexual products of fish than in muscle tissue $[63,64]$. This is also confirmed by studies $[65,66]$, according to which the most common forms of polychlorinated biphenyls (Arochlor 1254) in the ecosystem of the gulf of Escambia (Florida) are distributed as follows: in water-up to $1 \mathrm{mg} / \mathrm{L}$, in fish muscles- $4.5 \mathrm{mg} / \mathrm{kg}$, in fish liver-76-184 $\mathrm{mg} / \mathrm{kg}$.

In the literature, there is a huge number of research work related to the description of the accumulating ability and stability of hydrobionts in relation to heavy metals $[11,12,67]$. 
At the same time, the authors note that the level of bioaccumulation of heavy metals by hydrobionts is due to a variety of environmental factors affecting it [67]. Particular attention is paid to the issues of biological availability of certain heavy metals, taking into account the environmental conditions, as well as the characteristics of a particular reservoir $[13,14,68]$.

According to the research of A. A. Klenkin et al. [69], done in 2000-2005, the metal content in the liver of Sander lucioperca from the Azov Sea was higher than in the muscles for zinc by 2.5 times for males and 2.0 times for females, for copper by 3.1 and 4.6 times, respectively, for cadmium 2.0 and 12 times. In contrast to these elements, the concentration of lead was often higher in the muscle tissue of the studied fish than in their liver.

According to a number of other authors, copper, zinc and cadmium ions enter the body of fish mainly with food [70], but in conditions of a lack of trace elements in food and a high concentration of heavy metal in water, the arrival of water also plays a significant role [71,72].

In general, a similar result was founded by Karpyuk and co-authors [73], noting that metals and other toxicants enter the fish body directly from water in the process of biosorption through the gills and skin-parenteral nutrition, and as part of food through the food tract-oral alimentation. The high concentrations of cadmium and zinc in the fish are in values higher than their MPL, according to a number of scientists $[70,74]$ is explained by their presence in the cells of other aquatic organisms that form the basis of the food chain for these species.

In the scientific literature, there is also information that inorganic complexes or free ions have a high penetrating power in the fish body $[75,76]$. At the same time, there are known data [77] on high lipophilicity and high penetrating power of organo-metallic mercury and aluminum fluoride complexes in relation to the body of hydrobionts. The toxicants that enter the fish body are mainly deposited in fat formations, i.e., the concentration of contaminants in fat reserves is much higher than in other fish organs. These fat reserves are used by fish as energy sources, for example in winter, during spawning migration, etc. [64].

Thus, the results described above indicate not only the high level of contamination by toxic compounds in the Caspian Sea water, but also the significantly higher accumulation of them in the muscles, various fish organs and other aquatic organisms and plants of the water body.

\subsubsection{Biodiversity Conditions}

According to experts of the Caspian States [48,50], the ecosystem status quo of the Caspian Sea including its northern part is under anthropogenic stress and ecological regression. A decrease in species diversity and the reduction in its biological productivity, especially stocks of Acipenseridae and Pusa caspica have been observed as a result of contamination within both the Volga and the Ural River basins and by anthropogenic activities along the shorelines and the water body of the Caspian Sea.

In the Kazakh sector of the Caspian Sea, sturgeon catches decreased by 10 times between 2008 and 2010. The status quo of Caspian seal stocks is of great concern. It is classified as the endangered species on the International Union for Conservation of Nature's (IUCN) Red List. At present, there is a critical situation for the further existence of Pusa caspica. The entire north-eastern Caspian Sea is covered by oil operations all year round-drilling wells, construction of artificial islands, marine structures, digging trenches and laying pipelines, movement of numerous ships and helicopters. All of them have changed the habitual way of life of Pusa caspica with severe consequences for them. In addition, systematic chemical contamination of organisms has been increasing. Under these conditions, the number of deaths both seals and fishes has increased.

Great number of seals deaths in the Kazakh sector of the Caspian Sea were registered in 1968, 1978, 1997, 2000, 2001, 2006, 2007 and in 2009 [78-80]. There is no clear answer yet about the reasons for the death of seals. The main cause of their death in 1997, 2000 and 2007, according to the Commission members, [79] is considered epizootic by canine distemper virus, although at the same time there was a mass death of sturgeon. At the 
same time, it was noted [81] that the infection of seals occurred against the background of the sharp decrease in their immunity due to long-term chemical contamination of the Caspian Sea and chronic polytoxicity, mainly by petroleum products and pesticides.

According to full-scale visual observations of S. S. Kobegenova [78], during spring 2000, a next mass death of Pusa caspica occurred. The number of dead individuals, according to Caspian Fisheries Management Research Institute, in the Russian coast approached 11 thousand. On the Kazakh coast, the number of corpses washed ashore reached 50 thousand. Along the northern border of Dagestan to Derbent (Russia) 15-20 thousand dead Pusa caspica were counted. In addition, a significant number of dead fish, e.g., Acipenseridae, Rutilus rutilus, Clupeidae, were observed on the Dagestan coast.

Unfortunately, a systematic analysis of this tragedy, which is essentially for the ecological disaster for the Caspian region, has not been carried out. The fact of the accident was hidden, and the «Environmental Information Bulletin of the Republic of Kazakhstan» in 2000 stated that the main cause of the death of Pusa caspica was an epizootic virus «dog plague» $[78,80]$.

At the same time, it should be noted that the mass death of seals is usually detected visually in the early spring period, after ice melting in the shallow south-eastern sector of the Northern Caspian Sea.

Toxicological studies have proved [82-85] that saturation of the aquatic environment with various contaminants leads to functional accumulation, that is, the increase in the degree of damaging effects of toxicants on the fish body. With prolonged exposure, harmful substances are able to accumulate to toxic levels in the fat tissue, internal organs and muscles of the fish. As a result, their resistance to infectious and invasive diseases, as well as adverse environmental factors, is weakened.

According to P. P. Geraskan and others [86,87] and V. I. Lukyanenko [88], the strongest impact on fish was caused by the combination of petroleum hydrocarbons-organochlorine pesticides, the high level of which in the water of the Northern Caspian Sea occurred in 1988, when the deep change in the physiological state of sturgeon was noted due to the manifestation of signs of muscle tissue stratification and weakening of the caviar shell.

Taken water samples during spring 2006 from the area of mass death of seals and fish showed high concentrations of heavy metals exceeding the MPC 3-54 times, phenols, petroleum products, and other toxicants. In the muscle tissues of dead fish, the metal concentration exceeded MPL by 5-21 times, and in the liver by 29 times.

Analysis of the circumstances of seal death suggests that the entry of various toxic compounds into the Caspian Sea environment is either the cause of direct poisoning of animals, or one of the main factors leading to their death [79].

In the thirties of the last century, their number reached 1 million heads, in 1990 it was 300-400 thousand heads, in 2005, according to the international group of scientists (CISS), their number is estimated at 111 thousand, and in 2010-about 100 thousand [89-92]. In the Russian Federation, the Caspian seal is a commercial object and, for example, as for 2017 the total allowable catch (TAC) for the Russian lake share was approved in the amount of 6000 heads, with a TAC for the Caspian Sea of 12,000 heads [93].

These accounting results reveal the true picture of the habitat deterioration. And the frequent mass deaths of animals in the Kazakh sector of the Caspian Sea are the main reason for the catastrophic decline in their numbers.

In the near future, the intensive exploitation of hydrocarbon resources may finally destroy the Caspian Sea and its flora and fauna. The danger for the lacustrine environment caused by oil and petroleum hydrocarbons water pollution, can be tracked through a wide-scale and almost continuous flow of these contaminants to the lacustrine biota [94]. Being in various migration forms, they have the complex negative impact on water, soil and hydrobionts. The environmental hazard of oil transformation products in the lacustrine environment in the process of their further combined interaction with other contaminants has been experimentally proved and often causes synergy. 
It was established [95] that the Caspian Sea got contaminated by petroleum hydrocarbons before oil production, since the construction of wells, drilling processes are carried out using special materials and chemical reagents of various degrees of toxicity. The conducted experiments showed the presence of petroleum hydrocarbons in drill fluids used for gadding and bore muds occur in concentrations that can contaminate the lacustrine environment to levels exceeding the fisheries MPC $(0.05 \mathrm{mg} / \mathrm{L})$ if these oil products enter the lacustrine environment.

Experimental studies conducted by L.D. Kovalenko and others [96] and S.N. Garanina [97] showed the presence of negative effects of drilling mud, sludge and crude oil on zooplankton organisms, even with minor contamination of the aquatic environment by these toxicants. It was experimentally proved that the active process of dissolving crude oil with the increasing content of extracted petroleum hydrocarbons occurs in the lacustrine environment after 10 days [95].

A further exacerbation of the ecological state of the Caspian Sea is expected in connection with the escalation of oil production in all sectors of the Caspian states [98]. Even with the maximum observance of environmental safety measures, the use of modern technology, advanced methods of oil exploration, exploitation, and transportation, a contamination of the water body is not excluded.

\subsection{The Problem of the Caspian Sea Level Decline}

One of the most difficult problems in the ecology of the Caspian Sea is the intensive decline of its water level in recent decades. Changing the Caspian Sea level is a natural process that has a long-term cyclical character [99]. The main reason for fluctuations in the water level of the Caspian Sea, as established by long-term observations $[100,101]$, is the river flow entering the lake mainly through Volga and Ural Rivers.

The most reliable information about the Caspian Sea level has been available since 1990 [102]. From the beginning of instrumental observations and until the 20th century, the level of the Caspian Sea fluctuated in average around minus $25 \mathrm{~m}$. In the last century, the level of the Caspian Sea, almost until the end of the 1970s, mainly decreased (Figure 18).

The total continuous decrease in the level observed in 1930 . . 1977 made $3.2 \mathrm{~m}$. In 1977, the Caspian Sea level reached its lowest mark for the observation period-minus $29.01 \mathrm{~m}$. The decrease in the level was due to the fact that from the mid 1930s at the rivers of the Caspian basin began intensive water management construction, the impact of which became most noticeable in the 1950s. By the early 1970s, almost all major rivers in the basin were regulated. As a result, the volume of river runoff has decreased; the area of the Caspian Sea water surface has decreased. According to [103], the value of the reduced area was about 50 thousand $\mathrm{km}^{2}$. In the northeastern part of the North Caspian Sea the coastline lowered by $120 \ldots 140 \mathrm{~km}$ [104]. The lowering of the level caused large complications in the operation of the ports at the Caspian coast and sharply worsened the conditions of navigation, especially in the Northern Caspian Sea. The salinity of the water of the Northern Caspian Sea increased, which affected the condition of the food supply for small fish and Acipenseridae fish. Since 1978, an intensive Caspian Sea level rise began, which lasted for 18 years (1978 ... 1995). During this time, the Caspian Sea level rose by $2.5 \mathrm{~m}$, and by 1995 it reached minus $26.62 \mathrm{~m}$.

The rise of the Caspian Sea level has led to new problems related to flooding of coastal areas. According to studies [103], as a result of the water level rise the area of the flooded territories increased $35 \ldots 40$ thousand $\mathrm{km}^{2}$. In some areas, the coastline has advanced by 25 ... $50 \mathrm{~km}$. About 100 thousand people and industrial facilities were relocated from the flooding zones. 


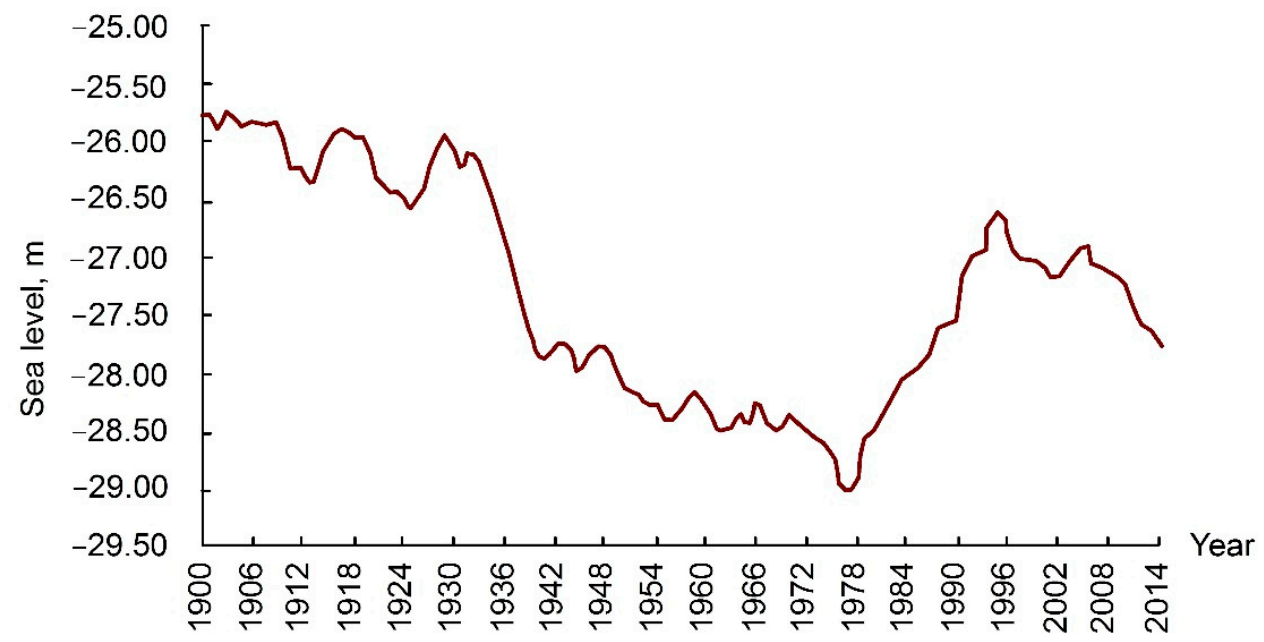

Figure 18. Long-term fluctuations of the Caspian Sea level [104].

In 1995, the Caspian Sea level rise slowed down, and in 1996 a decrease was observed mainly due to low water input coming from the Volga basin. From 1997 to 2001, the mean annual Caspian Sea level dropped by $19 \mathrm{~cm}$. In 2001, it reached minus $27.17 \mathrm{~m}$. The average annual Caspian Sea level in 2005 was minus $26.91 \mathrm{~m}$ b.s.l. [102]. Since 2006, the level of the Caspian Sea has been declined. In 2010, it reached minus $27.25 \mathrm{~m}$. By the end of 2014, it reached minus $27.82 \mathrm{~m}$. The value of the current decrease in the level relative to 1995 is $1.08 \mathrm{~m}$. The background Caspian Sea level for the period from 1900 to 2014 amounted to minus $27.28 \mathrm{~m}$ b.s.l., i.e., below the average long-term level by $42 \mathrm{~cm}$.

The decrease of the Caspian Sea level is most expressed in the northeastern, shallow part, which belongs to Kazakhstan. In fact, the coast of the Caspian Sea in the Kazakh sector is a flat plain with an extremely insignificant slope, from $1 \mathrm{~m}$ elevation difference for $10 \ldots 20 \mathrm{~km}$.

According to satellite images mapping, the drainage area in the northeastern part of the Caspian Sea amounted to $5055 \mathrm{~km}^{2}$ between 2005 and 2015. The morphometric characteristics have changed: new islands and bays have been formed. In some areas, the Caspian Sea coast retreated by $25 \mathrm{~km}$ [102]. For the entire Caspian Sea during this period, the area of the water surface has decreased by more than 11 thousand $\mathrm{km}^{2}$, and half of it is in the Kazakh part of the Northern Caspian Sea.

In accordance with the forecast of Roshydromet (Russian Hydrometeorological Survey) in 2015, the level is expected to decrease by $20 \ldots 30 \mathrm{~cm}$. As the researchers note, the probability that the lake level will continue to decrease in the coming years is very high [105].

According to [106] river runoff and evaporation have the biggest impact on long-term fluctuations of the Caspian Sea level. Moreover, it is known that the flow of the Volga River accounts for $80 \%$ of the total volume of river inflow into the Caspian Sea. And due to evaporation, the Caspian Sea level decreases by average of $97 \mathrm{~cm}$ per year. For the long term prospective, the role of these factors was assessed by the authors according to certain scenarios of climate change and water consumption in the basin. The calculated results for the Representative Concentration Paths (Scenarios for the evolution of anthropogenic greenhouse gas emissions into the atmosphere in the future) RCP 4.5 and RCP 8.5 scenarios showed that the inflow of water into the Caspian Sea has no expressed trend. Calculations of precipitation and evaporation have shown stable trends, from which it follows that evaporation from the Caspian Sea surface area will increase as a result of the prospected increase in air temperature. The inflowing part of the water balance of the Caspian Sea will not have serious changes, and the "outflow part" evaporation will increase, which can affect the decrease of the Caspian Sea level and the reduction of its water area. 
According to N.I. Ivkina et al. [107], during the current decrease of the Caspian Sea level (2006 . . . 2019), the average inflow into the Caspian Sea decreased by $7.5 \%$ relative to its average long-term value, the least precipitation amount was in the area of the Caspian Sea, and evaporation processes were more intensive, moreover, due to the series of dry years in the Volga River basin. The main reason for this low water period is climate warming, which has spread throughout the entire northern hemisphere [108]. The authors come to the conclusion that the level fluctuations of the Caspian Sea are mainly due to the ratio of the characteristics of the water balance, which are changing under the influence of anthropogenic climate change.

T.V. Kolch [109] has presented a forecast of Caspian Sea level changes for the near future. According to the author's calculations, and according to their first version (the first period), the lake level in 2020 should reach the mark of $-26.85 \mathrm{~m}$ b.s.l, and in 2030 $27.10 \mathrm{~m}$ b.s.l. According to the second version of the calculation, the level of the Caspian Sea in 2020 will be at the level of $-27.05 \mathrm{~m}$ b.s.l, and 2030 of $-27.85 \mathrm{~m}$ b.s.l. Therefore, by 2030, the lake level for the first option will be at the level registered in 2010, and for the second it will reach approximately the level of 1993, i.e., it will fall by $75 \mathrm{~cm}$. According to the data received from the National Hydrometeorological Organizations of the Caspian littoral states [110], the mean level of the Caspian Sea in 2019 decreased by about $17 \mathrm{~cm}$ as compared to 2018 ( $-28.03 \mathrm{~m}$ b.s.l) and amounted to $-28.20 \mathrm{~m}$ b.s.l. According to N.I. Ivkina and A.V. Galayeva [107] the average level of the Caspian Sea in 2020 was 28.3 mb.s.l. Comparing these real measured data with the foreast data of T.V. Kolch [109] can be mentioned that the Caspian Sea level decreased more as forcasted.

It should be noted that against the background of high anthropogenic contamination of the north-eastern part of the Caspian Sea, the intensive dropping down of the water level in this shallow zone, will cause a further deterioration of the environmental conditions of this water area with serious consequences for nearly all species habitats. Under such conditions of a decreasing water mass, the concentration of various toxic compounds increases sharply. This may be the cause of mass death of fish, seals and other aquatic organisms in this zone. In recent years, as a result of Caspian Sea regression, the vast seal rookeries on Durneva Island lose their former significance, due to drying out of shallow approaches and overgrowing surfaces [91,93].

\section{Assessment of the Results}

\subsection{Quantitative Assessment of the Environmental Safety Level of the Kazakh Part of the Caspian Sea}

The quality and quantity of water resources flowing into the Caspian Sea from river streams directly affect the water quality in the Caspian Sea. Both shallow water in the Kazakh part and water most close to the mouth of the rivers are especially vulnerable. This is associated with the pollution of water resources from river basins, threaten the existence of the unique and fragile ecosystem of the shallow waters of the Caspian Sea, which may also disappear due to the emerging trend of Caspian Sea level regression. In this regard, it is not possible to assess the impact of the water resources quality on the ecological stability and conditions of the ichthyofauna in without systematic and comprehensive studies of the entire Caspian Sea water area. Nevertheless, today a decrease in the biodiversity of lacustrine life of the Caspian Sea is evident, for example, Acipenseridae by more than an order of magnitude, and Pusa caspica by 4 times comparing with the recorded maximum population (from 1930-2010) [89-91,111].

Environmental sustainability (environmental safety-ES) and biodiversity of the ecosystem of the Northern Caspian Sea directly depend on the quantity and quality of the incoming water from the main river basins of Volga and Ural. An equally significant contribution to the pollution of the water body of the Caspian Sea comes from the production and development of hydrocarbons directly on the shelf itself.

Under these conditions bioindication methods that perfectly reflect the ecological quality of the organisms' habitat are an effective tool of comprehensive international studies 
of the ecological conditions of the Caspian Sea and its feeding streams in combination with water quality analyses. Monitoring methods for determining the quality of the aquatic environment based on bioindication methods are quite common and are occasionally used for various water bodies as an environmental assessment, or to confirm their disastrous conditions. Bioindication first of all, is an assessment tool reflecting anthropogenic or experiencing anthropogenic influences of environmental factors based on changes in the quantitative (or qualitative) characteristics of biological objects and systems [112,113].

It is well known that living organisms react very dynamically to various toxic compounds. Thus, they can be used as indicators of the environment. Bioindication allows an integral assessment based on the quality conditions of the aquatic ecosystem and the biota inhabiting it in various water bodies and areas. Bioindication at the same time is a very valuable informative complex, in combination with statistical methods. It can be used simple and convenient for the monitoring of different environmental compartments, such as river and lake systems, soils and the atmosphere. Not all organisms can serve as indicators. Therefore, the issues of compiling a list of indicators that are most applicable for the study of specific pollution in a particular environment are being discussed [114]. This was shown in the work on ecological mapping of river and Caspian Sea pollutions based on this method [115]. For decades Polish scientists have successfully used mosses as an indicator of the atmospheric environment when studying pollution by heavy metals at the national, regional and local levels [116].

Studying the quality of the aquatic environment of the Northern Caspian Sea, scientists [117] came to the conclusion, that as objects of bioindication preferable masswidespread species (not "rare" and not "disappearing") are suitable, because for them long-term results and regular observations are available. According to these data, the best bioindicators of the lacustrine ichthyofauna are massive representatives of the suborder Gobioidei from the genus Neogobius: Neogobius fluviatilis, Neogobius gymnotrachelus, Neogobius iljini and Neogobius melanostomus. Caspian Neogobius are an essential part of the Acipenseridae diet, Clupeidae, Stenodus leucichthys, Aspius aspius, Sander lucioperca and Pusa caspica. Neogobius's share nutrition of adult Acipenser and Huso huso reaches $80 \%$ of the total food mass. In the food of a seal in winter and summer, gobies make up to $40 \%$ of the diet.

As controlled variables of toxicological research they use the concentration of substances, such as organochlorine pesticides and heavy metals (lead, copper, zinc, mercury) in the tissues of internal organs and muscles of fishes.

Studies are often limited to assessing the impact of aquatic quality to one representative species of aquatic life, or sometimes cover an entire taxon $[118,119]$. In the first case it is impossible to reliably assess the whole complex of pollution impacts on the aquatic environment. However, to assess the impact of one or two conventional pollutants on water bodies is reliably. In the second case it is very difficult to isolate those factors that have a significant impact on the ecological conditions of the aquatic environment. But with a sufficient level of research it is possible to obtain real results.

Neither method can be a sufficient alternative to full-fledged studies of the ecological sustainability of the northern part of the Caspian Sea, since they are mainly focused on flowing river or lake closed ecosystems. The Caspian Sea with its number of unique features (sea-like lake currents, variable salinity, huge size, zoning of climatic factors) is very difficult to consider as a closed ecosystem.

\subsection{Methodology for Quantitative Assessment of the Ecological Safety Level}

In this regard, we propose a comprehensive (according to: the topography of the Caspian Sea bed, the pollution level, the composition of the pollution, the kind of anthropogenic impact) zonally distributed assessment of the environmental sustainability based on bioindication methods:

1. estimation of the average amount of lacustrine biota per volume unit (or water surface area for the objects, for example, shallow water); 
2. biodiversity of lacustrine fauna;

3. absorption of representative pollutants by the lacustrine ichthyofauna.

Since all indicators are measured in different units, their relative assessment will be correct, which will allow a convenient way, based on probabilistic methods of analysis, to consolidate these indicators.

We propose to estimate the average amount of lacustrine biota $(\mathrm{Kqb})$ in relation to the fixed population maximum (base level) by weight per unit volume, i.e.,:

$$
\mathrm{K}_{\mathrm{qb}}=\frac{\mathrm{qb}_{\mathrm{t}}}{\mathrm{qb}_{0}},
$$

where $\mathrm{qb}_{\mathrm{t}}$ is the number of biota per unit area obtained on the basis of current measurements, $\mathrm{qb}_{0}$ is the number of biota per unit area obtained on the basis of basic measurements.

The biodiversity assessment (Kbio) in this case is a zonal feature, assessed for a certain natural water area of the Caspian Sea (shallow water), which is also determined in relation to the base parameter based on the relative structure of the represented species of marine fauna:

$$
\mathrm{K}_{\mathrm{bio}}=1-\frac{1}{\mathrm{n}} \times \sum_{\mathrm{i}}\left|\frac{\mathrm{D}_{0}^{\mathrm{i}}-\mathrm{D}_{\mathrm{t}}^{\mathrm{i}}}{\mathrm{D}_{0}^{\mathrm{i}}+\mathrm{D}_{\mathrm{t}}^{\mathrm{i}}}\right|,
$$

where $D_{0}^{i}$ is the average share of the $\mathrm{i}$-th species of lacustrine fauna characteristic of the studied area of the Caspian Sea in the base period, $\mathrm{D}_{\mathrm{t}}^{\mathrm{i}}$ is the average share of the i-th species of lacustrine fauna typical for the studied area of the Caspian Sea in the current (studied) period, $n-$ number of species of lacustrine fauna participating in the assessment.

The assessment of water pollution (Kp) is carried out by an indication method based on the species of lacustrine animals most sensitive to certain pollutants. In this regard, the most suitable indicators of water pollution are commercial fish species or other organisms consumed by humans for food, for which the permissible values of sanitary standards, certain substances are determined. Secondly, the migration of lacustrine life over a large territory already averages the impact of local sources of the Caspian Sea pollution (ports, pipeline sections, river mouths, offshore oil platforms), which significantly increases the reliability of the data.

$$
\mathrm{K}_{\mathrm{p}}=\frac{1}{\mathrm{n}} \times \sum_{\mathrm{i}} \frac{\mathrm{SN}_{\mathrm{j}}^{\mathrm{i}}}{\mathrm{SN}_{\mathrm{j}}^{\mathrm{i}}+\mathrm{N}_{\mathrm{j}}^{\mathrm{i}}}
$$

where, $\mathrm{SN}_{\mathrm{j}}^{\mathrm{i}}$ are the sanitary standards for the number of permissible values of the $\mathrm{i}$-th harmful substances for the $j$-species of lacustrine inhabitants most vulnerable to this pollutant, $\mathrm{N}_{\mathrm{j}}^{\mathrm{i}}$ is the amount of harmful substances, $\mathrm{n}$ is the number of studied species of ichthyofauna.

The level of ecological sustainability (ES) of the investigated part of the Caspian Sea is determined on the basis of an aggregated assessment of the three indicators discussed above:

$$
\mathrm{ES}=\mathrm{K}_{\mathrm{qb}} \times \mathrm{K}_{\mathrm{bio}} \times \mathrm{K}_{\mathrm{p}} \times 100 \%
$$

In this regard, we used probabilistic methods for analyses in the most favorable situation. The level of environmental sustainability is close to $100 \%$. The deterioration of the environmental situation accordingly reduces the level of environmental sustainability of the system (Table 6).

Thus, a quantitative assessment of the ecological safety level of a part of the Caspian Sea on the basis of bioindication methods requires inexpensive additional systemic studies. Most importantly is the possibility of monitoring and constant ecological observation over an extremely vulnerable lacustrine ecosystem. 
Table 6. Assessment of the ecological safety level.

\begin{tabular}{cc}
\hline Level of Ecological Safety & Indicator (ES) \\
\hline favourable & $70-100 \%$ \\
\hline medium & $50-70 \%$ \\
\hline nonfavourable & $30-50 \%$ \\
\hline catastrophic & Less than $30 \%$ \\
\hline
\end{tabular}

\section{Conclusions and Recommendations}

During the meeting of the Kazakh-Russian Commission on the use of transboundary rivers held in Atyrau (2014), the ecological condition of the Ural River was called critical. This assessment is based on: the sharp reduction in water flow in the lower reaches, the high level of man-made contamination in the territory of the Russian Federation and the loss of conditions for natural reproduction of particularly valuable sturgeon species in the rivers. In 2016, Kazakhstan and the Russian Federation signed the agreement on the conservation of the Ural River ecosystem. The joint effort was planned to reduce cross-border river contamination, to protect fish resources, etc. However, measures to restore the ecological conditions of the river systems have not yet been undertaken. Therefore, in joint interstate negotiations on transboundary rivers it is necessary to pay attention to the acute problems of preserving the water resources of the Ural River.

As shown by our research $[21,34,41,99]$, technogenic pollution of the surface waters of the Ural River basin has been increased all the time causing a strong disturbance of the ecological balance of the river ecosystems. A large amount of suspended matter, biogenic elements, heavy metals, and anthropogenic pollutants enter the river. According to longterm observations, there is a stable pollution of watercourses which by many parameters exceeds the MPC for open water bodies. Currently, there is a tendency of increasing pollution of the Ural River.

In connection with the escalation of oil production in all sectors of the Caspian states, the ecological condition of the Caspian Sea is further aggravated. Even with the maximum observance of environmental safety measures, the use of modern technology, progressive methods of exploration, exploitation and oil transportation, pollution of the reservoir is not excluded [94-98].

Our study has proved that the main pollutants of the Caspian Sea are heavy metals, oil products, pesticides and polychlorinated biphenyls, which can accumulate in the muscles and in various organs of fishes.

Against the background of high anthropogenic pollution of the northeastern part of the Caspian Sea, an intensive lake level decrease in this shallow water zone is responsible for further deteriorations of the ecological condition of this water area with serious consequences for the living conditions. Under the conditions of decreasing water masses, the concentrations of currently entering various toxic compounds in large quantities increase sharply. This can be the reason for the mass death of fishes, seals and other aquatic organisms living in this area.

Under these conditions, the developed methodology for quantitative assessment of the ecological safety level for a part of the Caspian Sea, based on bioindication methods, makes it possible to monitor and continuously control the ecological stability of the Caspian Sea ecosystem continuously.

Therefore, in order to preserve the normative quality of water resources in the UralCaspian basin, the improvement of both the ecological conditions and habitat of hydrofauna is recommended in the following way:

1. organize ecological monitoring of water bodies with the receipt of periodic relevant information to assess the pollution of water resources based on the proposed methodology, based on the integrated application of bioindication methods;

2. organize permanent monitoring of negative impact sources in the Ural River basin; 
3. conduct research aimed to secure the sustainable functioning of terrestrial and aquatic ecosystems in the Ural-Caspian basin;

4. establish systematic observations of contaminants into the Ural River from Russian and Kazakh cities, including Uralsk and Atyrau for at least one annual discharge cycle;

5. be guided by the principles of the Helsinki Convention on the protection and use of transboundary watercourses and international lakes, and other international agreements on the protection of transboundary waters when addressing the issue of rational mutually beneficial use of the Ural River resources;

6. take drastic measures to prevent contamination of the Elek River;

Our research on the Kazakh sector of the Caspian Sea has shown that environmental problems here are extremely complex, which arose mainly due to the increased development of oil and gas resources exploitation by all Caspian states, both in off shore areas and in coastal territories.

Regarding the Kazakh sector of the Caspian Sea, it is recommended:

1. to establish systematic ecological-toxic and biological research across the entire water area of the Kazakh sector of the Caspian Sea to create its own database and promptly address protection issues for lacustrine ecosystems and for the use of its bioresources;

2. to establish strict analytical control over the inflow of contaminants into the Caspian Sea via the trans-border rivers Ural and Kigash;

3. to take measures to eliminate sources of contamination in the south-eastern shallow water zone of the Northern Caspian Sea, where seasonal concentrations of seals occur, while the death of seals and sturgeon species is registered;

4. to carry out measures for improved biodiversity monitoring systems with participation of all Caspian states.

5. in cases of loss of lacustrine fish and seals, take urgent measures to comprehensively study the causes of emergency situations with the mandatory involvement of independent experts and specialists of the Caspian states, taking into account that the Caspian Sea is an international body of water.

Author Contributions: Conceptualization, N.A.A., C.O., M.A. and A.R.M.; methodology, N.A.A., A.M., C.O. and A.R.M.; software, N.A.A. and M.A.; validation, N.A.A., C.O., A.M. and A.R.M.; formal analysis, N.A.A., C.O. and M.A.; investigation, N.A.A., A.M. and R.K.; resources, N.A.A., A.R.M.; data curation, N.A.A. and R.K.; writing-original draft preparation, N.A.A. and M.A.; writingreview and editing, C.O.; visualization, N.A.A., M.A. and R.K.; supervision, N.A.A., C.O. and A.R.M.; project administration, N.A.A. and C.O.; funding acquisition, M.A., A.M. and A.R.M. All authors have read and agreed to the published version of the manuscript.

Funding: The study was carried out within the framework of the scientific and technical program 0.0458 "Comprehensive ecological and epidemiological survey of the biocenosis of the Caspian water area and development of measures for its improvement for 2008-2010". Source of funding: Kazakh state budget and other regional projects.

Institutional Review Board Statement: We didn't use humans and living animals in the research process. In this regard, our research cannot relate to the requirements of the Helsinki Convention. For the analysis, individual dead fish samples were used to analyze their contamination with toxicants.

Informed Consent Statement: Not applicable.

Data Availability Statement: Not applicable.

Acknowledgments: We acknowledge the Kazakh state support of the scientific and technical program 0.0458 "Comprehensive ecological and epidemiological survey of the biocenosis of the Caspian water area and development of measures for its improvement for 2008-2010" for project funding and the permanent support by the Institute of Geography and Water Security, Ministry of Education \& Science, Almaty, Kazakhstan.

Conflicts of Interest: The authors declare no conflict of interest. 


\section{References}

1. Abu-Zeid, M.; Shiklomanov, I.A. Water Resources as a Challenge of the Twenty-First Century. Tenth IMO Lecture; World Meteorological Organization (WMO): Geneva, Switzerland, 2003.

2. FAO. The State of World's Land and Water Resources for Food and Agriculture Organization of the United Nations; FAO: Rome, Italy, 2011; p. 308.

3. Cosgrove, W.J.; Loucks, D.P. Water management: Current and future challenges and research directions. Water Resour. Res. 2015, 51, 4823-4839. [CrossRef]

4. Mukheibir, P. Water access, water scarcity, and climate change. Environ. Manag. 2010, 45, 1027-1039. [CrossRef] [PubMed]

5. UNESCO. Managing Water under Uncertainty and Risk. The United Nations World Water Development; UNESCO: Paris, France, 2012; Report 4; Volume 1.

6. Alves, M.T.R.; Teresa, F.B.; Nabout, J.C. A global scientific literature of research on water quality indices: Trends, biases and future directions. Acta Limnol. Bras. 2014, 26, 245-253. [CrossRef]

7. Takenov, Z.; Panchenko, N.; Sarsenbekov, T. Water Resources of Kazakhstan in the New Millennium. Review; Astana, Kazakhstan, 2012; p. 120. (In Russian)

8. Medeu, A.R.; Malkovsky, I.M.; Toleubayeva, L.S. Water Resources of Kazakhstan: Assessment, Forecast, Management; Resources Streamflow of Kazakhstan: Almaty, Kazakhstan, 2012; Volume 1, p. 90. (In Russian)

9. Toleubayeva, L.S. Water Resources of Kazakhstan: Assessment, Forecast, Management Volume XIV. Water Availability of the Republic of Kazakhstan: Status and Prospects (for Official Use); Almaty, Kazakhstan, 2012; p. 238. (In Russian)

10. Opp, C. Schwermetalle; Bastian, O., Schreiber, K.-F., Eds.; Analyse und ökologische Bewertung der Landschaft: Berlin, Germany, 1999; pp. 239-246.

11. Grunewald, K.; Weber, C.; Schröder, K. Schadstoffbelastung und Auennutzung nach dem Elbehochwasser 2002 in Sachsen-eine Synopse. Handbuch für Angewandte Limnologie. Handb. Angew. Limnol. 2005, 22, 1-42. [CrossRef]

12. Weber, C.J.; Opp, C. Schwermetallverteilung in Böden, Fließgewässern und Grubenwässern im Umfeld des ehemaligen Eisenerzabbaugebietes Dillenburg-Oberscheld, Lahn-Dill-Kreis. Geol. Jb. Hessen 2018, 139, 201-218.

13. Hahn, J.; Opp, C.; Ganzenmüller, R.; Ewert, A.; Schneider, B.; Zitzer, N.; Laufenberg, G. Catchment soils as a factor of trace metal accumulation in sediments of the reservoir Klingenberg (Eastern Ore Mountains, Germany). J. Environ. Sci. 2019, 86, 1-14. [CrossRef] [PubMed]

14. Iordache, A.M.; Sandru, C.; Voica, C.; Zgavarogea, R.; Miricioiu, M.G.; Ionete, R.E. Assessment of Heavy Metals Pollution in Sediments from Reservoirs of the Olt River as Tool for Environmental Risk Management. Rev. Chim. 2020, 70, 4153-4162. [CrossRef]

15. Iordache, A.; Iordache, M.; Sandru, C.; Voica, C.; Stegarus, D.; Zgavarogea, R.; Ionete, R.E.; Ticu, S.C.; Miricioiu, M.G. A Fugacity Based Model for the Assessment of Pollutant Dynamic Evolution of VOCS and BTEX in the Olt River Basin (Romania). Rev. Chim. 2019, 70, 3456-3463. [CrossRef]

16. Opp, C. Organische Schadstoffe; Bastian, O., Schreiber, K.-F., Eds.; Analyse und ökologische Bewertung der Landschaft: Berlin, Germany, 1999; pp. 246-249.

17. Weber, C.J.; Opp, C. Spatial patterns of mesoplastics and coarse microplastics in floodplain soils as resulting from land use and fluvial processes. Environ. Pollut. 2020, 267, 115390. [CrossRef]

18. Burlibaev, M.Z.; Fashchevski, B.B.; Opp, C.; Burlibaeva, D.M.; Kaidarova, R.K.; Vagapova, A.P. Environmental Flow Standardization of Kazakh Rivers; Almaty, Kazakhstan, 2014; p. 407. (In Russian)

19. Sivokhip, Z.T.; Pavleichik, V.M.; Chibilev, A.A.; Padalko, Y.A. Problems of sustainable water use in the transboundary basin of the Ural River. Water Resour. 2017, 44, 504-516. (In Russian) [CrossRef]

20. Surface Water Resources of the USSR. Volume 12. Issue. 2. Ural-Ebinsky District; Hydrometeoizdat: Leningrad, Soviet Union, 1970; p. 511. (In Russian)

21. Medeu, A.R.; Amirgaliev, N.A.; Davletgaliev, S.K.; Sergaliev, N.H.; Akhmedov, K.I. Assessment of water resources of transboundary rivers of the Ural-Caspian basin. In Proceedings of the International Scientific and Practical Conference "Geoecological Problems of Steppe Regions", Nature Conservation and Regional Development: Harmony and Conflict, Orenburg, Russia, 1-5 October 2017; Volume 1, pp. 32-45. (In Russian).

22. Sergaliev, N.H.; Akhmedenov, K.M.; Abisheva, S.H.; Gavrillina, I.I. Analysis of data on hydrochemical and toxicological indicators of the Zhaiyk river in West Kazakhstan and Atyrau regions. In Proceedings of the Materials of the International Scientific and Practical Conference "Water Resources of Central Asia and Their Use", Dedicated to Summing Up the Results of the UN Decade "Water for Life", Almaty, Kazakhstan, 22-24 September 2016; pp. 418-423. (In Russian)

23. Sergaliev, N.H.; Ahmedhanov, K.M.; Anaev, M.K.; Abisheva, S.H.; Gavrilin, I.I. Chemical-ecological assessment of rivers in West Kazakhstan region. Small rivers of the Kazakhstan-Orenburg cross-border region. In Collection of Scientific Articles; Makhambet Utemisov West Kazakhstan University: Uralsk, Kazakhstan, 2015; pp. 153-161. (In Russian)

24. Pavleichik, V.M.; Sivokhip, Z.T. Formation of surface water quality in the basin of the upper reaches of the Ural River under technogenic transformation of the environment. Water Resour. 2013, 40, 499-509. (In Russian) [CrossRef]

25. Kuzhina, G.S.; Yanturin, S.I. Investigation of heavy metal pollution of bottom deposits of the upper reaches of the Ural river. Bull. Orenbg. State Univ. 2009, 6, 582-584. (In Russian) 
26. MADEP-EPH-98-1. Method for Determination of Recoverable Petroleum Hydrocarbons; Massachusetts Environmental Protection Department: Boston, MA, USA, 1998; p. 41. (In Russian)

27. Kashintsev, M.L.; Stepanenko, B.S.; Anisova, S.N. (Eds.) Generalized List of Maximum Permissible Concentrations (MPC) and Tentatively Safe Exposure Levels (TSEL) of Harmful Substances for Waters of Fishery Reservoirs; All-Union Scientific Research Institute of Marine Fisheries and Oceanography: Moscow, Russia, 1990; p. 46. (In Russian)

28. Collection of Sanitary and Hygienic Standards and Methods for Controlling Harmful Substances in Environmental Objects; International Conversion Fund, Center for Environmental Problems: Moscow, Russia, 1991; p. 370. (In Russian)

29. Water Quality Standards for Fishery Water Bodies, Including Standards for Maximum Permissible Concentrations of Harmful Substances in the Waters of Fishery Water Bodies; Federal Agency for Fisheries of the Russian Federation: Moscow, Russia, 2010 ; p. 406. (In Russian)

30. Sanitary and Epidemiological Requirements for Water Sources, Places of Water Intakes for Domestic and Portable Water Supply and Places of Cultural and Domestic Water Use and Safety of Water Bodies; Minister of National Economy of the Republic of Kazakhstan: Astana, Kazakhstan, 2015; Volume 209, p. 31. (In Russian)

31. Fomin, G.S. Water. Control of Chemical, Bacterial and Radiation Safety According to International Standards. Encyclopedic Reference Book, 3rd ed.; Publishing House "Protector": Moscow, Russia, 2000; p. 848. (In Russian)

32. Salnikov, N.E. Impact of Multiple Discharge of Waste Water from the Orenburg Oil Refinery on Soil Contamination and Benthic Fauna of the Ural River; Materials of the International Scientific Conference Dedicated to the 70th Anniversary of ASU; Astrakhan University: Astrakhan, Russia, 2000; Volume 2, pp. 182-184. (In Russian)

33. Stockholm Convention on Persistent Organic Pollutants; Stockholm, Sweden, 2001; p. 53. (In Russian)

34. Amirgaliyev, N.A.; Askarova, M.A. Persistent organic pollutants in the water of transboundary basins of Kazakhstan. In Proceedings of the Materials International Scientific-Practical Conference "Water Resources of Central Asia and their use" Devoted to the Summing-Up of the "Water for Life" Decade Declared by the United Nation, Almaty, Kazakhstan, 22-24 September 2016; Volume 3, pp. 45-55.

35. Amirgaliev, N.A. Polychlorinated Biphenyls in the Water Ecosystem of the Ili-Balkash Basin; Nurayprint Service LLP: Almaty, Kazakhstan, 2016; p. 192. (In Russian)

36. Klyuyev, N.A.; Brodskiy, Y.S. Determination of Polychlorinated Biphenyls in the Environment and Biota. Polychlorinated Biphenyls. Supertoxicants of the XXI Century; Inf. Issue VINITI: Moscow, Russia, 2000; Volume 5, pp. 31-63. (In Russian)

37. Drinking Water. Sanitary Rules and Regulations; 2.1.4.559-1996; Moscow, Russia, 1996; p. 110. (In Russian)

38. Monitoring and Methods of Environment Control; The International Independent University of Environmental and Political Sciences: Moscow, Russia, 2001; p. 337. (In Russian)

39. Maistrenko, V.N.; Klyuyev, N.A. Ecological and Analytical Monitoring of Persistent Organic Pollutants; BNNOM: Moscow, Russia, 2004; p. 323. (In Russian)

40. Zhakovskaya, Z.A.; Petrova, V.N.; Khoroshko, L.O.; Kukhareva, G.I.; Lukin, A.A. Polychlorinated biphenyls and hydrocarbons in bottom sediments of Pechora Basin Rivers. Water Resour. 2010, 37, 75-83. (In Russian) [CrossRef]

41. Amirgaliyev, N.A. Assessment of the level of anthropogenic pollution of the Elek River. Issues Geogr. Geoecol. 2013, 1, 11-18. (In Russian)

42. Information Bulletin on the State of the Environment of the Republic of Kazakhstan for 2018; RSE "Kazhydromet": Astana, Kazakhstan, 2018; p. 409. (In Russian)

43. Monakhov, S.K. State of the Natural Environment and Functioning of the Ecosystem of the Northern Caspian Sea. Environmental Protection in the Search, Exploration and Production of Hydrocarbons in the Northern Part of the Caspian Sea; SE PPC "Volga": Astrakhan, Russia, 2003; pp. 135-160. (In Russian)

44. Burlibaev, M.Z. (Ed.) Globally Significant Wetlands in Kazakhstan (The Ural River Delta and the Adjacent Caspian Sea Coast); “Printing House Complex" LLP: Astana, Kazakhstan, 2007; Volume 1, p. 264. (In Russian)

45. Veremeyenko, O.V.; Shcherbakova, Y.N.; Monoyuva, G.A. Surface Chemical Runoff to the Caspian Sea from the Territory of the Russian Federation. Problems of Preserving the Caspian Ecosystem in the Conditions of Development of Non-Gas Fields; Caspian Scientific Institute of Fisheries: Astrakhan, Russia, 2009; pp. 26-30. (In Russian)

46. Laskorin, B.N.; Lukyanenko, V.I. The Problem of Water Quality in the Volga-Caspian Basin. Physiological and Biochemical Status of the Volga-Caspian Sea Sediments in Normal and in the Case of Muscle Tissue Stratification (Cumulative Polytoxinosis); Institute of Biology of Inland Waters of the USSR Academy of Sciences: Rybinsk, Russia, 1990; pp. 6-24. (In Russian)

47. Katunin, D.N. Ecological and Toxicological Characteristics of the Volga-Caspian Basin in Modern Conditions. Fisheries Research in the Caspian Sea: Results of Research for 2000; Caspian Scientific Research Institute of Fisheries: Astrakhan, Russia, 2001; pp. 52-69. (In Russian)

48. Kurochkina, T.F. Modern ecological and toxicological state of reservoirs of the Volga-Caspian basin. Sci. Bull. Casp. Float. Univ. 2001, 2, 38-45. (In Russian)

49. Rylina, O.N. Ecological and Toxicological Monitoring of the Volga-Caspian Basin. In Fisheries Research on the Caspian Sea: Results of Research for 2002; Caspian Scientific Research Institute of Fisheries: Astrakhan, Russia, 2003; pp. 54-74. (In Russian)

50. Yegorov, S.N.; Rylina, O.N. Ecological and Toxicological Characteristics of the Lower Reaches of the Volga River and the Caspian Sea. In Fisheries Research on the Caspian Sea: Results of Research for 2005; Caspian Scientific Research Institute of Fisheries: Astrakhan, Russia, 2006; pp. 44-65. (In Russian) 
51. Amirgaliyev, N.A.; Taljanov, N.A. The level of toxicants in the water of the North-eastern part of the Caspian Sea (2008-2010, cadmium, zinc, copper, lead, petroleum hydrocarbons). In Atlas of Atyrau Region; "Institute of Geography" LLP: Almaty, Kazakhstan, 2014; pp. 217-220. (In Russian)

52. Prikhodko, T.V.; Smirnova, S.Y.; Mikhaleva, M.M.; Talzhanov, N.A.; Balpanov, D.S. Investigation of water and bottom sediments of the Northern Caspian Sea for the content of petroleum products and pesticides. In Collection of the International Scientific Conference on Analytical Chemistry and Ecology; Chemistry Series; Bulletin Kazakh National University: Almaty, Kazakhstan, 2010; Volume 60, p. 69. (In Russian)

53. Mukhamedyarova, E.M.; Suyunova, A.B.; Bezrodnov, M.A.; Globa, N.V.; Talzhanov, N.A.; Balpanov, D.S. Environmental monitoring of the ichthyofauna of the Kazakhstan sector of the Caspian water area for oil, pesticides and heavy metals contamination. In Ecology, Health, Sport; Trans-Baikal State University: Chita, Russia, 2009; pp. 312-314. (In Russian)

54. Suyunova, A.B.; Globa, N.V.; Bezrodnov, M.A.; Talzhanov, N.A.; Balpanov, D.S. Investigation of the ichthyofauna of the Kazakhstan sector of the Caspian water area for oil, pesticides and heavy metals contamination. In International Scientific Conference on Analytical Chemistry and Ecology; Chemistry Series; Bulletin of Kazakh National University: Almaty, Kazakhstan, 2010; Volume 60, pp. 79-80. (In Russian)

55. Amirgaliev, N.A.; Talzhanov, N.A.; Prikhodka, T.V.; Suyunova, A.B. The level of toxicants in commercial fish species of the Caspian Sea. In Atlas of the Atyrau Region; “Institute of Geography” LLP: Almaty, Kazakhstan, 2014; pp. 232-235. (In Russian)

56. Amirgaliev, N.A. The level of heavy metal pollution in the Kazakhstan water area of the Caspian Sea. In Modern State of Bioresources of Inland Reservoirs; Akvaros: Moscow, Russia, 2011; Volume 1, pp. 16-21. (In Russian)

57. Prikhodko, T.V.; Smirnova, S.Y.; Kazieva, L.M.; Talzhanov, N.A.; Balpanov, D.S. Content of toxic metals in water and bottom sediments in the Kazakhstan sector of the Caspian Sea. In Collection of the 1st International Scientific and Practical Conference "Ecology, Health, Sport"; Trans-Baikal State University: Chita, Russia, 2009; pp. 319-321. (In Russian)

58. Medical and Biological Requirements and Sanitary Standards for the Quality of Food Raw Materials and Food Products; Official Publication; Standards: Moscow, Russia, 1990; p. 79. (In Russian)

59. SanPin № 4.01.071-2003. Sanitary Requirements for the Safety and Nutritional Value of Food Products; Almaty, Kazakhstan, 2006; p. 200. (In Russian)

60. Hygienic Standards for the Content of Pesticides in Environmental Objects; Information and Publishing Center of Goskomsanepidnadzor of Russia: Moscow, Russia, 1997; p. 52. (In Russian)

61. Amirgaliev, N.A.; Timirkhanov, S.R.; Isbekov, K.B. Water Resources of Kazakhstan: Assessment, Forecast, Management. Volume XIV. Fisheries of Kazakhstan: Status and Prospects (For Official Use); ARKO: Karaganda, Kazakhstan, 2012; p. 667. (In Russian)

62. Semenov, A.D. The problem of pollution of the Azov Sea with pesticides. Bull. Use Prot. Nat. Resour. Russ. $2005,4,36-41$. (In Russian)

63. Orachinskiy, K.K. On the accumulation of pesticides in hydrobions. Hydrobiol. J. 1970, 4, 126-131. (In Russian)

64. Moroz, I.E. Methods of Ichthyolotoxicological Research; Ministry of Fishery of the Soviet Union: Leningrad, Soviet Union, 1987; p. 123. (In Russian)

65. Duke, T.W.; Lowe, J.J.; Wilson, A.J. A polychlorinated biphenyl (Aroklor 1254) in water, sediment and biofa of Es Kawfia Bay, Florida. Bull. Environ. Contam. Toxicol. 1974, 5, 171-180. [CrossRef]

66. Nansen, D.J.; Parrish, P.K.; Lowe, J.I.; Wilson, A.J. Chronic toxicolty, suptake and revenuion of Arochlor in two estucerine fishes. Bull. Environ. Contamin. Toxicol. 1971, 6, 113-119.

67. Ramamurti, S. Heavy Metals in Natural Waters; Mir: Moscow, Russia, 1987; pp. 285-286. (In Russian)

68. Chukhlebova, L.M.; Berdnikov, M.V.; Ponesenko, N.M. Heavy metals in water, bottom sediments and muscles of fish of the Amur river. Hydrobiol. J. 2011, 47, 110-120. (In Russian) [CrossRef]

69. Klenkin, A.A.; Korablina, I.V.; Korpakovai, G. Heavy metals in commercial fish of the Sea of Azov. Quest. Fish. 2009, 9, 503-512. (In Russian)

70. Brown, D.A.; Bay, S.M.; Hershelman, G.P. Exposure of scorpion fish (Scorpaena guttata) to cadmium: Effects of acute and chronic exposure on the cytosolic distribution of cadmium, copper, and zinc. Aquat. Toxicol. 1990, 16, 295-310. [CrossRef]

71. Kamunde, C.N.; Grosell, M.; Higgis, D.; Wood, C.M. Copper metabolism in actively growing rainbow trout interactions between dietary and waterborne cooper uptake. J. Exp. Boil. 2002, 205, 279-290. [CrossRef]

72. Kuznetsova, A.J.; Zarubina, O.V.; Leonova, G.A. Comparison of $\mathrm{Zn}, \mathrm{Cu}, \mathrm{Pb}, \mathrm{Ni}, \mathrm{Cr}, \mathrm{Sn}$, Mo concentrations in tissues of fish (roach and perch) from Lake Baikal and Bratsk reservoir, Russia. Environ. Geochem. Health 2002, 24, 205-212. [CrossRef]

73. Karpyuk, M.I.; Zubchenko, I.A.; Sokolsky, A.F. Theory of Biosorption of Aquatic Animals (Scientific Bases and Practical Use); Publishing AGTU House: Astrakhan, Russia, 2002; p. 333. (In Russian)

74. Andreji, J.; Stranai, I.; Massanyi, P.; Valent, M. Accumulation of some metals in muscles of five species from lower Nitra River. J. Environ. Sci. Health 2006, 41, 2607-2622. [CrossRef]

75. Campbell, P.G.C. Interaction between trace metals and aquatic organisms: A critique of the free-ion activity model. In Metal speciation and Bioavailability in Aquatic Systems; J. Willey: London, UK, 1995; pp. 45-102.

76. McGeer, J.C.; Szebedinszky, C.; McDonald, D.G.; Wood, C.M. The role of dissolved organic carbon in moderating the bioavailability and toxicity of $\mathrm{Cu}$ to rainbow trout during chronic waterbourne exposure. Comp. Biochem. Physiol. 2002, 133, 147-160.

77. Heath, A.G. Water Pollution and Fish Physiology; Lewis Publ.: London, UK, 2002; p. 506. 
78. Kobegenova, S.S. Problems of Preserving the Biological Diversity of the Caspian Sea. In Prospects for Sustainable Development of Ecosystems of the Caspian Region, Materials of the Scientific and Practical Conference; Kazakh University: Almaty, Kazakhstan, 2004; pp. 86-88. (In Russian)

79. Amirgaliyev, N.A.; Alpeyisov, S.A. Ecological and toxicological problems and the condition of biological resources of the Caspian Sea. In Caspian Dialogue 3, Materials of the International Conference; Public Organization "School of the XXI Century": Almaty, Kazakhstan, 2008; pp. 160-167. (In Russian)

80. Amirgaliyev, N.A. The Caspian seal, how to preserve it? In Ecological Education in Kazakhstan; Almaty, Kazakhstan, 2010; Volume 2, pp. 29-32. (In Russian)

81. Isbekova, K.B.; Amirgaliyev, N.A. Modern ecological problems and condition of biological resources of the Kazakhstan part of the Caspian Sea. In Science News of Kazakhstan. Scientific and Technical Collection; National Center for Scientific and Technical Information: Almaty, Kazakhstan, 2012; Volume 1-2, pp. 106-113. (In Russian)

82. Zemkov, G.V.; Zhuravlev, G.F. Kinetics of pathological changes in cumulative toxicosis in the body as a criterion of resistance of the fish population. In Success of Modern Natural Science; Academy of Natural Sciences: Philadelphia, PA, USA, 2004; Volume 1, pp. 41-52. (In Russian)

83. Fedrov, L.A.; Yablokov, A.V. Pesticides-Toxic Blow to the Biosphere and Man; Nauka: Moscow, Russia, 1999; pp. 462-465. (In Russian)

84. Lepine, F.L. Effects of ionizing radiation on pesticides in a food irradiation perspective: A bibliographic review. J. Agric. Food Chem. 1991, 39, 2112-2118. [CrossRef]

85. Lepine, F.L.; Brochu, F.; Milot, S. Gamma-irradiation-induced degradation of DDT and its metabolites in organic solvents. J. Agric. Food Chem. 1994, 42, 2012-2016. [CrossRef]

86. Geraskin, P.P. Metabolic disorders in Russian sturgeon in modern conditions of the Volga-Caspian Sea. In Sturgeon Farming of Reservoirs of the USSR; Caspian Scientific Research Institute of Fisheries: Astrakhan, Russia, 1989; pp. 60-62. (In Russian)

87. Geraskin, P.P.; Metallov, G.F.; Zhuravleva, G.F. The level of physiological well-being of Caspian sturgeon in the marine period of life under conditions of increased impact of anthropogenic factors. In Fisheries Research on the Caspian Sea; Caspian Scientific Research Institute of Fisheries: Astrakhan, Russia, 2002; pp. 423-436. (In Russian)

88. Lukyanenko, V.I. Influence of multi-factor anthropogenic press on habitat conditions, reproduction number and catches of sturgeon fish. In Physiological and Biological Status of the Volga-Caspian Sturgeon in Normal Conditions and in the Case of Muscle Tissue Stratification (Accumulation of Polytoxicosis); Institute of Biology of Inland Waters of the USSR Academy of Sciences: Rybinsk, Russia, 1990; pp. 25-44. (In Russian)

89. Harkonen, T.; Jussi, M.; Baimukanov, M.; Bignert, A.; Dmitrieva, L.; Kasimbekov, Y.; Verevkin, M.; Wilson, S.; Simon, J. Goodman pup production and breeding distribution of the Caspian seal (Phoca caspica) in relation to human impacts. Ambio 2008, 37, 356-361. [CrossRef]

90. Baimukanov, M.; Verevkin, M.; Wilson, S.; Goodman, S.; Dmitrieva, L.; Kasymbekov, E.; Harkonen, T.; Jussi, I.; Jussi, M. On the state of the population of the Caspian seal (Phoca Caspica). In Mater. International Scientific-Practical Conf., Dedicated to 75 th Anniversary of al-Farabi Kazakh National University and 75th Anniversary of the Faculty of Biology; ST "Aruna": Almaty, Kazakhstan, 2009; pp. 16-17. (In Russian)

91. Baimukanov, M.T. How to save the Caspian seal (Phoca Caspica). In News of the Academy of Sciences of the Republic of Kazakhstan; Biological and Medical Series; Institute of Biology and Biotechnology of Plants: Almaty, Kazakhstan, 2017; Volume 6, pp. 100-111. (In Russian)

92. Kuznetsov, V.V. Current state of the Caspian seal population. Bulletin of the Astrakhan State Technical University; Series of Fisheries; Astrakhan State Technical University: Astrakhan, Russia, 2017; Volume 1, pp. 35-45. (In Russian)

93. Harkonen, T.; Jussi, M.; Baymukanov, M.; Bignert, A.; Verevkin, M.; Wilson, S.; Dmitrieva, L.; Kasymbekov, E.; Goodman, S. Reproduction and distribution of the Caspian seal (Phoca caspica) during breeding and anthropogenic influence. Izv. NAS RK Ser. Biol. 2010, 5, 66-77. (In Russian)

94. Abdurakhmanov, G.I.; Akhmedova, G.A. Influence of pollution on the biodiversity of the Volga-Caspian basin. In Materials of the I-International Scientific and Practical Conference; Caspian Scientific Research Institute of Fisheries: Astrakhan, Russia, 2005; pp. 11-13. (In Russian)

95. Magamedov, A.K. Content of petroleum products in drilling fluids, slurries and destruction of oil in the marine environment. In Problems of Preserving the Caspian Ecosystem in the Conditions of Oil and Gas Fields Development; Caspian Scientific Institute of Fisheries: Astrakhan, Russia, 2009; pp. 134-137. (In Russian)

96. Kovalenko, L.D.; Panarin, A.P. Influence of drilling mud, sludge and crude oil on zooplankton organisms. In Problems of Preserving the Caspian Ecosystem in the Conditions of Oil and Gas Fields Development; Caspian Scientific Institute of Fisheries: Astrakhan, Russia, 2009; pp. 98-101. (In Russian)

97. Garanina, S.N. Influence of development of offshore oil and gas fields on the productivity of algae in the Caspian Sea. In Fisheries Research on the Caspian Sea: Results of Research for 2002; Caspian Scientific Research Institute of Fisheries: Astrakhan, Russia, 2003; p. 560. (In Russian)

98. Salmanov, M.A. The significance of oil pollution in the formation of the overall biological productivity of reservoirs (for example, the Caspian Sea). In Problems of Preserving the Caspian Ecosystem in the Conditions of Oil and Gas Fields Development; Caspian Scientific Institute of Fisheries: Astrakhan, Russia, 2009; pp. 184-188. (In Russian) 
99. Aminova, I.I.; Amirgaliev, N.A.; Bazarbayev, S.K.; Beknyazov, M.K.; Burlibayev, M.Z. Globally Significant Wetlands of Kazakhstan, Volume 1. The Delta of the Ural River and the Adjacent Coast of the Caspian Sea. Section 1. Water Resources and Environment; "Printing House Complex" LLP: Astana, Kazakhstan, 2007; pp. 13-78. (In Russian)

100. Kritsky, S.N.; Korenistov, D.V.; Redkovich, D.Y. Fluctuations in the Level of the Caspian Sea; Nauka: Moscow, Russia, $1975 ;$ p. 160. (In Russian)

101. Hydrometeoizdat. Hydrometeorology and Hydrochemistry of Lakes. Vol. VI. Caspian Sea. Issue 1; Hydrometeoizdat: Saint-Petersburg, Russia, 1992; p. 359. (In Russian)

102. Ivkina, N.I.; Terekhov, A.G.; Naurozbayeva, Z.K. Fluctuations in the level of the Caspian Sea and diagnostics of modern changes in the position of the coastline according to Landsat satellite data for the period 2005-2015. Hydrometeorol. Ecol. 2015, 2, 89-99. (In Russian)

103. Kosarev, A.N.; Nikonova, R.Y. On the causes and consequences of fluctuations in the level of the Caspian Sea in the XX-XXI centuries. Proc. State Oceanogr. Inst. 2008, 211, 127-151. (In Russian)

104. Kosarev, A.N.; Nikonova, R.Y. Modern fluctuations in the level of the Caspian Sea: Causes, consequences, trends. Casp. Bull. 2006, 60, 40-59. (In Russian)

105. Information Bulletin on the Condition of the Level of the Caspian Sea. 16 March 2015. Available online: http:/ /www.caspcom. com/files/CASPCOM_bulletin_2.pdf (accessed on 2 May 2021).

106. Ivkina, N.I.; Kaipov, I.V.; Galayeva, A.V. Assessment of possible changes in the characteristics of the water balance of the Caspian Sea under the influence of climate change. In Some Aspects of Hydroecological Problems of Kazakhstan: Collection of Scientific Papers of the KAPE. Release 2; Kaganat: Almaty, Kazakhstan, 2018; pp. 390-397. (In Russian)

107. Ivkina, N.I.; Galayeva, A.V. Changes in the main components of the water balance of the Caspian Sea under the influence of climate. Hydrometeorol. Ecol. 2020, 4, 16-28. (In Russian)

108. FGBU Research Center Planet. The Second Assessment Report of Roshydromet on Climate Changes and their Consequences in the Territory of the Russian Federation; FGBU Research Center Planet: Moscow, Russia, 2014; p. 59. (In Russian)

109. Kolch, T.V. Ecological aspects of long-term fluctuations in the water level of the Caspian Sea. In Prospects for Sustainable Development of Ecosystems of the Caspian Region. Materials of the Scientific and Practical Conference; Kazakh University: Almaty, Kazakhstan, 2004; pp. 25-27. (In Russian)

110. Coordinating Committee on Hydrometeorology of the Caspian Sea Information Bulletin on the State of the Caspian Sea Level No. 20. 30 October 2020. Available online: http:/ / www.caspcom.com/files/CASPCOM\%20Bulletin\%20No.\%2020_2.pdf (accessed on 2 May 2021).

111. Khodorevskaya, R.P.; Kalmykov, V.A.; Zhilkin, A.A. Current condition of sturgeon population in the Caspian basin and measures for their conservation. Vestnik AGTU Ser. Fish. Farming 2012, 1, 99-106.

112. Antsiferova, G.A. Bioindication of Water Ecosystems. Manual for Universities; VGU: Voronezh, Russia, $2014 ;$ p. 60.

113. Schubert, R. Bioindikation in Terrestrischen Ökosystemen; Fischer: Jena, Germany, 1985; p. 327.

114. Holt, E.A.; Miller, S.W. Bioindicators: Using Organisms to Measure Environmental Impacts. Available online: https://www. nature.com/scitable/knowledge/library/bioindicators-using-organisms-to-measure-environmental-impacts-16821310/ (accessed on 24 February 2021).

115. Barinova, S. Ecological mapping in application to aquatic ecosystems bioindication: Problems and methods. Int. J. Environ. Sci. Nat. Resour. 2017, 3, 36-42. [CrossRef]

116. Godzik, B. Use of bioindication methods in national, regional and local monitoring in Poland—Changes in the air pollution level over several decades. In Atmosphere; W. Szafer Institute of Botany, Polish Academy of Sciences: Kraków, Poland, 2020; Volume 11, pp. 143-158.

117. Puzachenko, A.Y.; Morozov, B.N.; Butylina, T.P.; Khodorevskaya, R.P. Monitoring of the Impact to the Condition of Ecosystems and Biodiversity in the Area of Developing Hydrocarbon Deposits in the Caspian Sea and Reducing Risks to the Biodiversity of the Northern Caspian Sea. Available online: https:/ / cyberleninka.ru/article/n/bioindikatsiya-kachestva-vody-reki-sviyagi-spomoschyu-vysshih-vodnyh-rasteniy/viewer (accessed on 24 February 2021).

118. Krasilnikova, N.S. Bioindication of the Water Quality of the Sviyaga River Using Higher Aquatic Plants. Available online: https: / / cyberleninka.ru/article/n/bioindikatsiya-kachestva-vody-reki-sviyagi-s-pomoschyu-vysshih-vodnyh-rasteniy/viewer (accessed on 24 February 2021).

119. Bespalova, Y.B. Methodology for integral assessment of the transformation of aquatic ecosystems. Vestnik VGU. Series Geograph. Geoecol. 2019, 1, 74-84. 